\title{
Processes Governing Alkaline Groundwater Chemistry within a Fractured Rock (Ophiolitic Mélange) Aquifer Underlying a Seasonally Inhabited Headwater Area in the Aladağlar Range (Adana, Turkey)
}

\author{
Cüneyt Güler, ${ }^{1}$ Geoffrey D. Thyne, ${ }^{2}$ Hidayet Tağa, ${ }^{1}$ and Ümit Yıldırım ${ }^{1}$ \\ ${ }^{1}$ Jeoloji Mühendisliği Bölümü, Mersin Üniversitesi, Çiftlikköy Kampüsü, 33343 Mersin, Turkey \\ ${ }^{2}$ Science Based Solutions, 2317 Mountain Shadow Lane, Laramie, WY 82070, USA \\ Correspondence should be addressed to Cüneyt Güler; cuneytguler@gmail.com
}

Received 12 January 2017; Accepted 27 April 2017; Published 15 August 2017

Academic Editor: Tobias P. Fischer

Copyright (C) 2017 Cüneyt Güler et al. This is an open access article distributed under the Creative Commons Attribution License, which permits unrestricted use, distribution, and reproduction in any medium, provided the original work is properly cited.

\begin{abstract}
The aim of this study was to investigate natural and anthropogenic processes governing the chemical composition of alkaline groundwater within a fractured rock (ophiolitic mélange) aquifer underlying a seasonally inhabited headwater area in the Aladağlar Range (Adana, Turkey). In this aquifer, spatiotemporal patterns of groundwater flow and chemistry were investigated during dry (October 2011) and wet (May 2012) seasons utilizing 25 shallow hand-dug wells. In addition, representative samples of snow, rock, and soil were collected and analyzed to constrain the PHREEQC inverse geochemical models used for simulating waterrock interaction (WRI) processes. Hydrochemistry of the aquifer shows a strong interseasonal variability where $\mathrm{Mg}-\mathrm{HCO}$ and $\mathrm{Mg}-\mathrm{Ca}-\mathrm{HCO}_{3}$ water types are prevalent, reflecting the influence of ophiolitic and carbonate rocks on local groundwater chemistry. R-mode factor analysis of hydrochemical data hints at geochemical processes taking place in the groundwater system, that is, WRI involving Ca- and Si-bearing phases; WRI involving amorphous oxyhydroxides and clay minerals; WRI involving Mg-bearing phases; and atmospheric/anthropogenic inputs. Results from the PHREEQC modeling suggested that hydrogeochemical evolution is governed by weathering of primary minerals (calcite, chrysotile, forsterite, and chromite), precipitation of secondary minerals (dolomite, quartz, clinochlore, and Fe/Cr oxides), atmospheric/anthropogenic inputs (halite), and seasonal dilution from recharge.
\end{abstract}

\section{Introduction}

Achievement of a sustainable aquifer management requires an improved understanding of the complex natural processes generating the observed composition of groundwater, as well as all anthropogenic activities hindering its safe use and availability [1]. This is critically important, especially in headwater areas, since they typically constitute $70-80 \%$ of the total catchment area [2] and represent starting point of the terrestrial water cycle [3]. Our understanding of the mountainous headwater systems and the impacts of anthropogenic activities on headwater-scale has been largely impeded by their small size, large numbers, remote locations, rugged terrain, harsh climate conditions, and lack of road access, logistics, and available data [4-7]. Despite their importance, in the literature, there is no clear definition as to what constitutes a "headwater area" $[4,8]$. It is generally agreed upon that these areas are unique and fragile recharge environments near the topographical drainage divides where flow lines of zeroto first-order catchments originate [7, 9]. Yet, because of the problem of scale dependency, most of these low-order stream channels are rarely documented on the topographic maps $[4,10]$; hence, they are frequently omitted from the ordering schemes (e.g., [11, 12]). In reality, these montane headwater systems serve as the transport medium for delivering water, sediment, nutrients, and other materials to downstream areas, especially during intermittent rainfall and snowmelt events $[4,6,10]$. Recently, Bishop et al. [5] called aptly this understudied and ignored realm as "Aqua Incognita," the unknown waters. A number of studies (e.g., [2, 6, 10, 13-15]) 
have shown that hydrological and hydrogeochemical processes occurring in headwater systems have critical control on the quantity and biophysicochemical quality of the underlying shallow groundwater and downstream systems, all of which are intimately linked through the hydrologic cycle. Furthermore, these areas and associated hyporheic zones have also important ecosystem functions, providing unique habitats for diverse flora, fauna, and microbiota [16-18] that are imperative for a fully functioning system.

During the last several decades, relatively poorly developed and remote highlands of the Aladağlar Range of eastern Taurides have become increasingly valued for their climatological and bioecological diversity (e.g., [19-21]), nearpristine water and air quality (e.g., $[21,22])$, scenic and aesthetic beauty (e.g., [20]), and recreational/touristic opportunities (e.g., [23]). Long before the recent appreciation of all these natural treasures/qualities, these highland areas (called yayla) were occupied essentially as summer camping grounds by the nomadic people (called Yörük) who commonly made their living by livestock rearing (primarily goat) and to a lesser extent small-scale family farming [24, 25]. While the pure nomadic lifestyle is still alive in some areas, currently, yaylas are mostly frequented by the city dwellers, especially during the summer season, due to their comfortable climate (e.g., cool and less humid) as compared to the Mediterranean coastal zone (i.e., Çukurova region) [19, 21]. As a response to this new trend, numerous seasonal settlements were created in the headwater areas, which in turn have not only significantly altered demographic, cultural, and socioeconomic characteristics of the region [21] but also had a marked impact on the natural environment [23, 24, 26-28].

Recent modeling studies conducted in the Seyhan River basin also raised concerns over the anthropogenic climate change, which is projected to aggravate the pressure on the hydrologic system in the forthcoming decades [29-31]. This paper presents the first detailed analysis of hydrological and hydrochemical data obtained from two snapshot sampling campaigns carried out in the Kizılgedik seasonal settlement, which is located in a serpentinized ophiolitic terrain in the headwaters of the Seyhan River basin. The specific objectives of the present study were (i) to define the mineralogy and geochemistry of the rocks and soils found in the area; (ii) to determine water levels and groundwater flow directions in the ophiolitic complex aquifer; (iii) to investigate possible effects of anthropogenic inputs to the underlying shallow aquifer; and (iv) to shed light on the predominant hydrogeochemical processes using inverse geochemical modeling approach.

\section{Study Area}

2.1. Physiographic Setting, Climate, and Land Use. The study area, located $\sim 100 \mathrm{~km}$ north of the Mediterranean Sea coastline in Adana province (Turkey), lies within the Aladağlar Range of eastern Taurides (Figures 1(a) and 1(b)) and is a part of the Seyhan River basin (area $21,700 \mathrm{~km}^{2}$ ). The specific area studied is bounded by the latitudes $37^{\circ} 31^{\prime} 55.50^{\prime \prime} \mathrm{N}$ and $37^{\circ} 32^{\prime} 28.70^{\prime \prime} \mathrm{N}$, and longitudes $35^{\circ} 25^{\prime} 10.75^{\prime \prime} \mathrm{E}$ and $35^{\circ} 25^{\prime} 52.51^{\prime \prime} \mathrm{E}$. This area encompasses a rugged mountainous terrain, with altitudes ranging from 1030 to $1310 \mathrm{~m}$ above mean sea level (msl), and it is characterized by topographic gradients between $0.13^{\circ}$ and $45.9^{\circ}$ (with a mean slope of $16.6^{\circ}$ and E-SE aspect). The climate is continental to some extent [19] and influenced by both the Mediterranean and central Anatolian weather systems, bringing temperate, dry summers, and cold, wet winters to the area [20]. Based on the available climate data (1960-1991) recorded at the Pozant1 meteorological station (see Figure 1(b)), the average annual air temperature is $13.5^{\circ} \mathrm{C}$ and temperatures occasionally exceed $31^{\circ} \mathrm{C}$ in summer and rarely drop below $-6^{\circ} \mathrm{C}$ in winter [32]. The area receives an average annual precipitation slightly higher than $725 \mathrm{~mm}$ and $85 \%$ of it occurs between November and May [32]. The precipitation occurs in winter, as rain and snowfall, but in summer as occasional thunderstorms.

In Kizılgedik site, there are 85 individual houses accommodating some 300 people during the peak season (June to September). However, population remains insignificant during the rest of the year (i.e., off-season). Currently, the area does not have a sewerage network and each property has its own cesspit in the garden. Traditionally, cesspits are built square in form (dimensions: $2 \mathrm{~m} \times 2 \mathrm{~m} \times 1.5 \mathrm{~m}$ ) and lined with loose-fitting stones allowing wastewater to percolate into the ground (Figure 2). There was no piped water supply until 2011, where majority of the residents still rely on large-diameter hand-dug wells (HDWs) (Figure 2) for their domestic water needs and irrigation. Typical of serpentinitic terrains, the natural vegetation in the settlement area is limited to sparse shrubs and herbaceous vegetation (a.k.a. serpentine barrens [35]), whereas domesticated plants and trees are mainly found around residential houses. Additionally, patches of mixed conifer forests (e.g., pine, juniper, larch, fir, and cedar) are often found in the hills surrounding the settlement area.

2.2. Geological and Hydrogeological Setting. The study area is situated in the east of the relatively isolated Karsantı basin (see Figure 1(b)), which formed during Oligocene time [34, 36-38] within the westernmost part of the eastern Taurides $[33,39]$, immediately to the north of the extensively studied Adana basin [40-45]. The geological formations found in the region range in age from Mesozoic to Cenozoic and represent highly complex tectonic and stratigraphic relationships [36, 46] (Figures 3(a) and 3(b)). Mesozoic rocks include the Late Triassic-Early Jurassic Etekli formation (megalodonbearing limestone) [36], Late Cretaceous Kızılcadağ ophiolitic mélange (serpentinized dunite and harzburgite, serpentinite, radiolarite, chert, and exotic blocks) [47], and Late Cretaceous Pozant1-Karsant1 ophiolite (harzburgite, dunite, pyroxenite, gabbro, diabase dykes, and metamorphic rocks) $[48,49]$. The Kızılcadağ ophiolitic mélange, tectonically overlain by the Pozant1-Karsantı ophiolite, contains thrust slices composed of Etekli formation [36]. The ophiolitic mélange is made up of blocks of heterogeneous and strongly deformed lithologies (i.e., exotic blocks decimeter to several hundreds of meters in size) set in a variably altered serpentinitic matrix [50]. Most of the serpentinites have probably formed during suboceanic hydrothermal alteration of ultramafic protoliths (e.g., harzburgite and dunite) prior to their emplacement on land. Pozant1-Karsantı ophiolite formed within the 


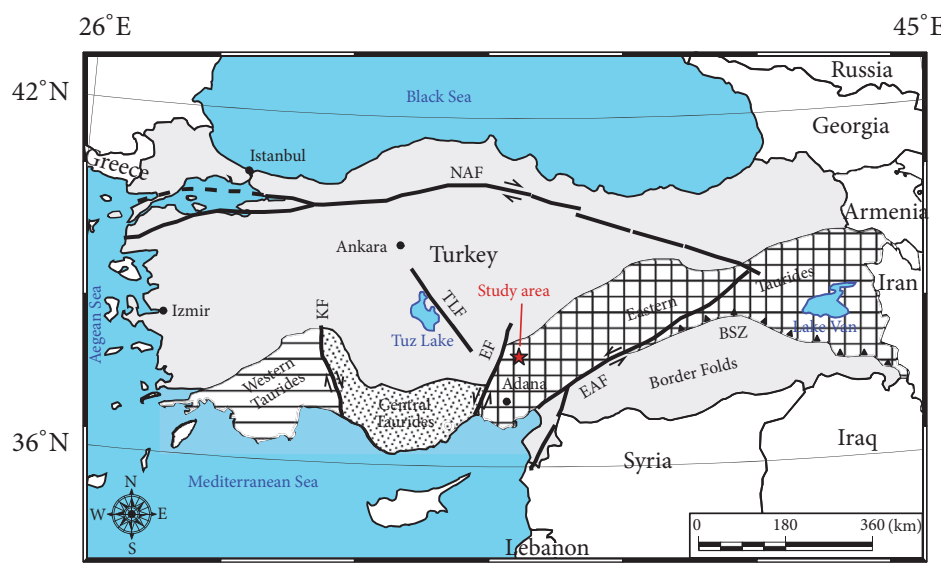

(a)

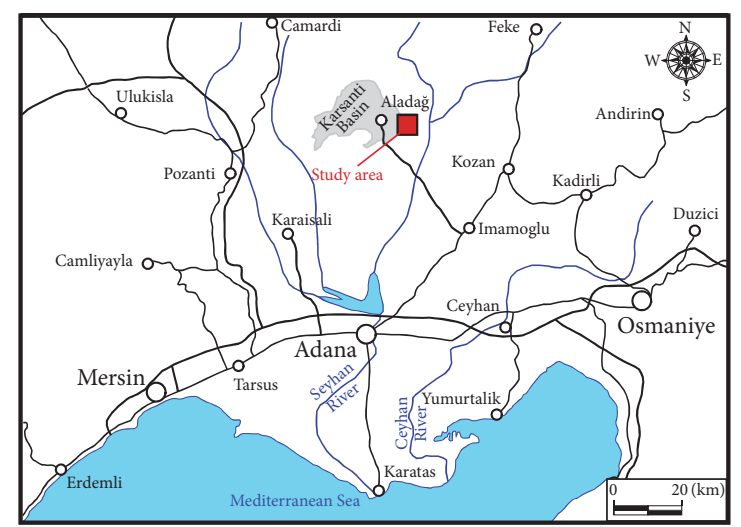

(b)

FIGURE 1: (a) The broad geographical subdivision of the Taurides (after [33]) and major tectonic structures in Turkey (KF = Kurkkavak Fault, $\mathrm{EF}=$ Ecemiş Fault, TLF $=$ Tuz Lake Fault, EAF $=$ East Anatolian Fault, NAF $=$ North Anatolian Fault, BSZ = Bitlis Suture Zone) $($ modified from [34]) and (b) location of the Kizılgedik study area in Aladağ (Adana, Turkey).

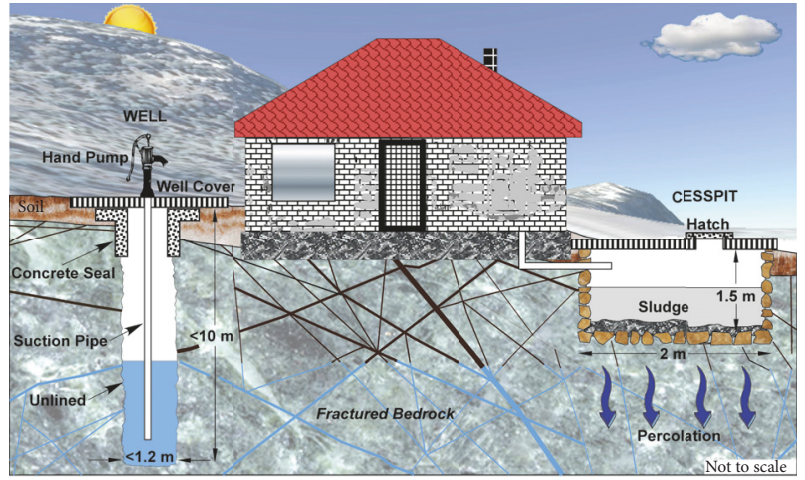

FIGURE 2: Schematic drawing showing typical designs of hand-dug wells and cesspits in the study area.

Neo-Tethys Ocean in the Middle to Late Cretaceous [51, 52]. Much of the large-scale deformation is related to regional compressional events that occurred during Late Eocene [34].

In the study area, Cenozoic sedimentation begins with the Oligocene-Late Miocene Karsantı formation (terrestrial and lacustrine pebbly sandstone, mudstone, coaly claystone, and marl) [43]. This formation is separated from the underlying Mesozoic tectonostratigraphic units by a distinct unconformity [53]. This nonmarine deposition ended in the Early Miocene by a transgression from the Adana basin [54]. The Early-Middle Miocene (AquitanianBurdigalian) Kaplankaya formation (shallow marine marl, claystone, sandstone, and sandy limestone) [45] records the first marine transgression in the Karsant1 basin [37]; the base of this unit also lies above an irregular unconformity surface [55]. Kaplankaya formation is partly overlain by and passes laterally into the Early-Middle Miocene (BurdigalianSerravallian) Karaisalı formation (fossiliferous reefal limestone) $[43,56]$. Karaisalı formation occupies topographically higher parts of the study area (e.g., Korum Mountain) and is highly susceptible to karstification, as evidenced by the prevalence of sinkholes. A detailed synthesis of both regional and local tectonic framework and evolution of the Karsant1 basin can be found in $[34,38]$.

Hydrologically, the study area resides within several zeroorder catchments that lie at the ultimate extremes of the local drainage network, where overland flow is only seen after heavy rainfall events and during snowmelt episodes in illdefined surface flow paths (e.g., rills, gullies, and swales). The aquifers within the study area can be classified into two primary groups based on host rock and structural characteristics, as follows: (i) carbonate rock aquifer and (ii) ophiolitic complex aquifer. Groundwater occurrence within the carbonate rocks is not known due to absence of monitoring wells, but secondary porosity created by fractures/faults, together with karstic features such as sinkholes, may allow significant groundwater circulation and enhanced recharge. Groundwater found within the ophiolitic complex aquifer is of utmost importance for the livelihood of the headwater environment and local residents, although ophiolitic rocks of this region have been considered impermeable in earlier studies $[57,58]$. In the study area, the ophiolitic complex aquifer is compartmentalized by a distinct set of faults, trending in SW-NE direction. In this aquifer, groundwater is tapped from the highly fractured portion of the ophiolitic mélange by shallow HDWs with depths not exceeding $10 \mathrm{~m}$. In the study area, recharge to the aquifers takes place through several ways, such as (i) infiltration from the runoff from precipitation and snowmelt events; (ii) lateral and downwards groundwater flow from the overlying geological formations (mostly karstic in nature); (iii) infiltration from irrigation water; and (iv) wastewater percolation from the cesspits. The main recharge areas are positioned to the N and SW of the study area (Figures 3(a) and 3(b)). Water levels in the ophiolitic complex aquifer respond relatively quickly to the recharge events, due to highly fractured nature of the upper portions of the ophiolitic mélange. The discharge from the aquifers occurs in different ways, including (i) subsurface outflow to adjacent valleys that moves through 


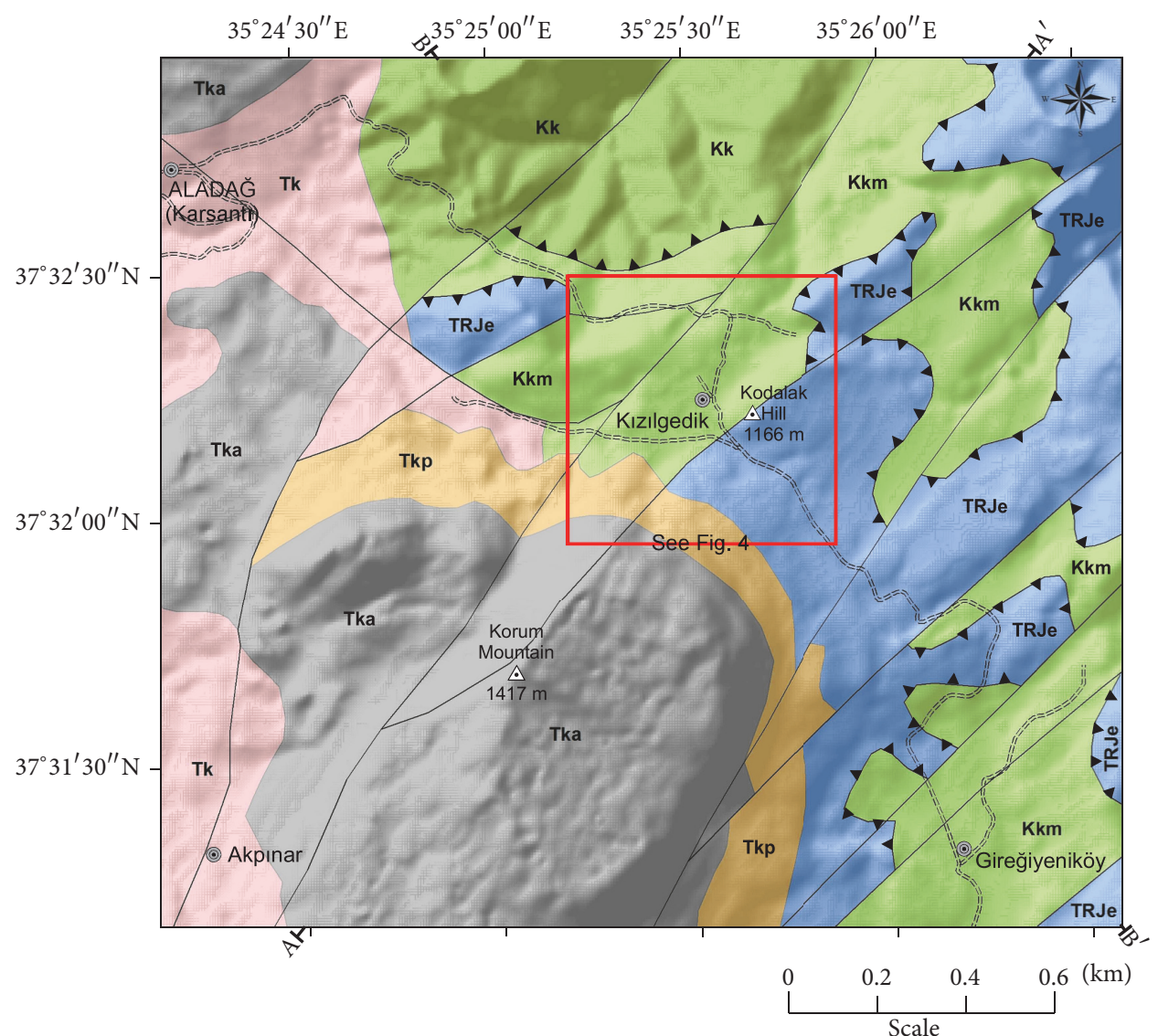

Geological formations

Tka Karaisal formation (Early-Middle Miocene) Transitional

Tkp Kaplankaya formation (Early-Middle Miocene)

mm Angular unconformity

$\mathrm{Tk}$ Karsantı formation (Oligocene-Late Miocene)

mm Nonconformity

Kk Pozantı-Karsantı ophiolite (Late Cretaceous)

- Overthrust

TRJe Etekli formation (Late Triassic-Early Jurassic)

- Overthrust

Kkm Kizılcadağ ophiolitic mélange (Late Cretaceous)

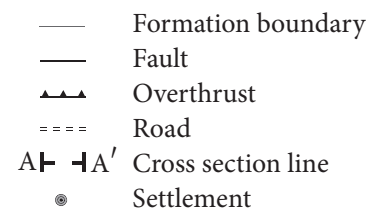

(-) Settlement

(a)
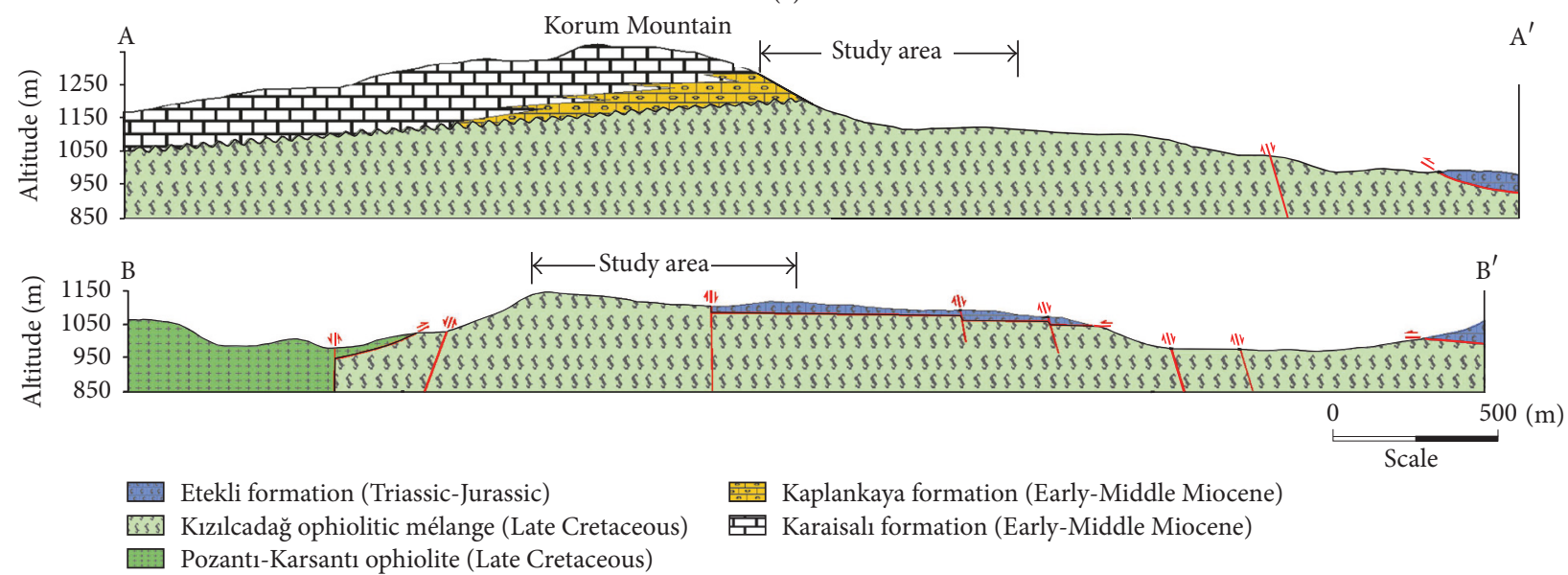

(b)

Figure 3: (a) Detailed geological map (adapted from [36]) of the region surrounding the Kizllgedik site (shown in the red box) overlaid on a digital elevation model (DEM) with a grid size of $10 \mathrm{~m}$ and (b) generalized geological cross sections along the lines $\mathrm{A}-\mathrm{A}^{\prime}$ (SW to NE) and $\mathrm{B}-\mathrm{B}^{\prime}$ (NW to SE) in (a) showing the subsurface lithology and major tectonic structures (faults shown in red color). 


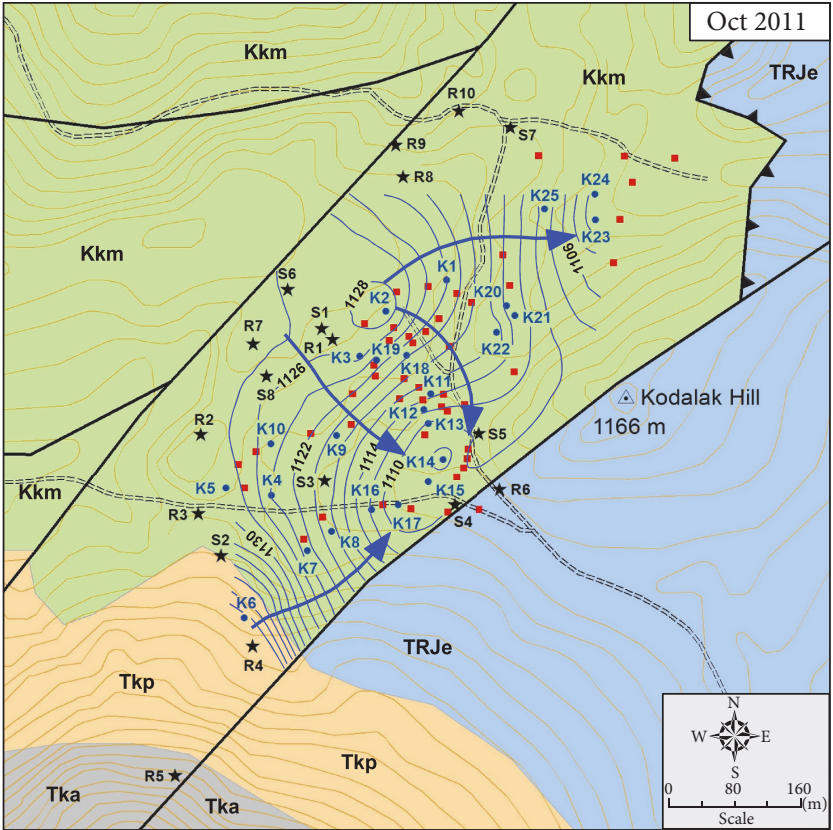

Geological formations

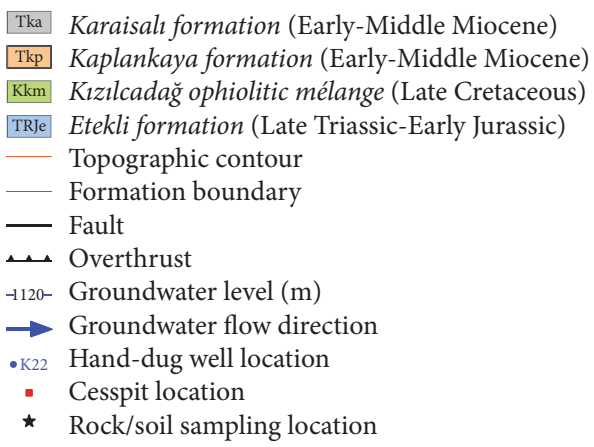

(a)

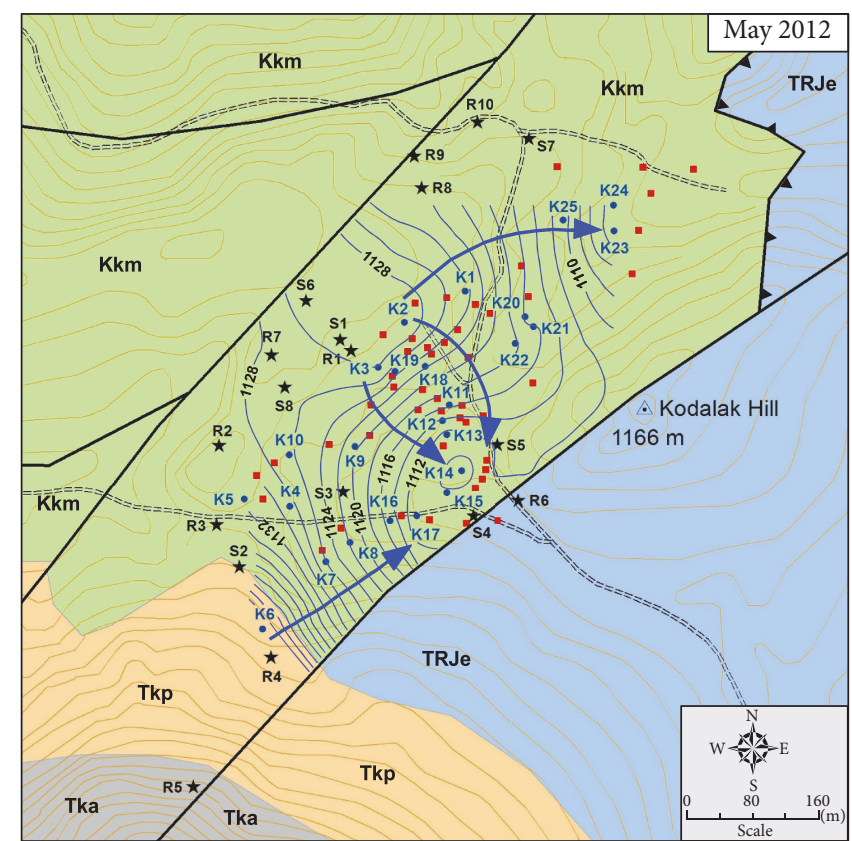

Geological formations

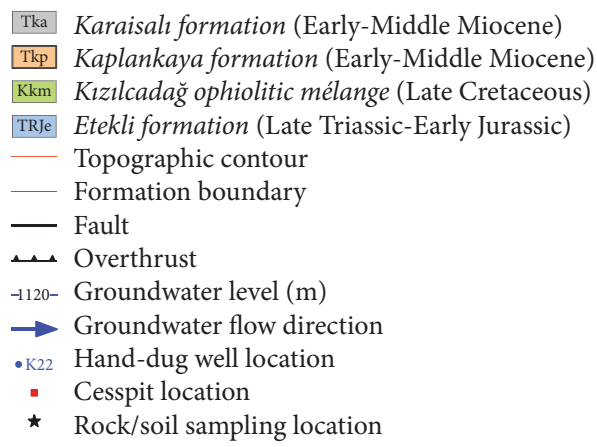

(b)

Figure 4: Hydrogeological map of the Kizllgedik study area (see red box in Figure 3(a)) showing locations of groundwater ( $n=25)$, rock ( $n=10)$, and soil $(n=8)$ sampling sites. The hand-dug well (HDW) codes (i.e., K1-K25) refer to both water table measurement and groundwater sampling sites. The water table elevations are given at intervals of $2 \mathrm{~m}$ above mean sea level (msl) for both (a) dry season (October 2011) and (b) wet season (May 2012). Arrows depict the general direction of shallow groundwater flow in the fractured ophiolitic complex aquifer.

fractures/faults; (ii) discharge by springs and seeps; (iii) evaporation of shallow groundwater; (iv) transpiration by plants; and (v) groundwater abstraction from HDWs.

\section{Materials and Methods}

3.1. Rock/Soil Sampling and Analytical Methods. A rock and soil sampling campaign was carried out in November 2013 in order to relate the groundwater chemistry with lithology. Selection of the sampling sites (see Figure 4) was largely based on spatial distribution of the major geological units and field observations made during prior on-site surveys. Fresh rock samples $(n=10)$ were collected at various locations (i.e., R1-R10), generally as composite chip samples $(\sim 1 \mathrm{~kg})$ from available outcrops with a rock hammer. Topsoil composite samples $(n=8)$ were collected at a depth of $0-15 \mathrm{~cm}$ with a stainless steel spatula, after removing stones, plant/root debris, and foreign objects. At each soil sampling site (i.e., S1-S8), representative composite samples were obtained by pooling four subsamples $(\sim 250 \mathrm{~g})$ taken on the corners of a $1 \mathrm{~m}^{2}$ square [59]. All samples were placed in labeled selflocking polyethylene bags and transferred to the laboratory for further processing. In the laboratory, the rock and soil samples were air-dried at room temperature for several days, disintegrated and homogenized in an agate mortar and then passed through a $2 \mathrm{~mm}$ sieve. Samples for X-ray diffraction (XRD), wavelength dispersive X-ray fluorescence (WDXRF), and loss-on-ignition (LOI) analyses were prepared by the usual powder method procedures as described by Buhrke et al. [60]. Rock and soil samples were ground to powder and 
homogenized by RS 200 tungsten carbide vibratory disc mill (Retsch, Germany) and then fine grinding was accomplished using an agate mortar and pestle.

The main mineral phases occurring in the rock and soil samples were characterized by powder XRD technique using a Rigaku SmartLab X-ray diffractometer (Rigaku Corporation, Japan) with $\mathrm{Cu} \mathrm{K} \alpha$ radiation at an accelerating voltage of $40 \mathrm{kV}$ and a tube current of $30 \mathrm{~mA}$. XRD patterns in diffractograms were obtained from $5^{\circ}$ to $60^{\circ}$ in $2 \theta$ with a step width of $0.02^{\circ}$, at a scanning speed of $4^{\circ} \mathrm{min}^{-1}$, using $1 \mathrm{~mm}$ receiving slits, a $10 \mathrm{~mm}$ length limiting slit, and a $2 / 3^{\circ}$ incident slit. The software PDXL and the PDF-2 database (http://www.icdd.com) were employed for mineral phase identification. The chemical composition of the rock and soil samples were determined by a Rigaku ZSX Primus II WDXRF spectrometer (Rigaku Corporation, Japan) with a $4 \mathrm{~kW}$ rhodium target, using an acceleration voltage of $30 \mathrm{kV}$ and a current of $100 \mathrm{~mA}$. The major oxides $\left(\mathrm{SiO}_{2}, \mathrm{TiO}_{2}\right.$, $\mathrm{Al}_{2} \mathrm{O}_{3}, \mathrm{Fe}_{2} \mathrm{O}_{3}, \mathrm{MnO}, \mathrm{MgO}, \mathrm{CaO}, \mathrm{Na}_{2} \mathrm{O}, \mathrm{K}_{2} \mathrm{O}, \mathrm{P}_{2} \mathrm{O}_{5}$, and $\mathrm{SO}_{3}$ ) and trace elements $(\mathrm{Co}, \mathrm{Cr}, \mathrm{Ni}$, and $\mathrm{Sr}$ ) in bulk solids were quantified using the standardless analysis program SQX [61].

WDXRF analyses were carried out on pressed-powder pellets that were prepared by thoroughly mixing $10 \mathrm{~g}$ of each sample with $4 \mathrm{~g}$ of cellulose binder (SPEX SamplePrep PrepAid ${ }^{\circledR}$, USA) with a particle size of $\leq 20 \mu \mathrm{m}$. The mixture was pressed into $38 \mathrm{~mm}$ diameter pellets using a manually operated hydraulic press. After pressing, the pellets were dried in oven at $100^{\circ} \mathrm{C}$ for $12 \mathrm{~h}$, before the WDXRF analysis. The LOI was determined as the weight loss percentage after burning $4 \mathrm{~g}$ of powdered dry sample in an electric muffle furnace at $950^{\circ} \mathrm{C}$ for $1 \mathrm{~h}[62,63]$. All analyses were performed at the Advanced Technology Education, Research and Application Center (MEITAM), Mersin University (Turkey).

3.2. Groundwater Level Measurement. The groundwater sample collection and water level measurements were completed within two days, in two separate field campaigns, covering all the wells. The field campaigns took place in October 2011 and May 2012. For convenience, the terms "dry season" and "wet season" will be used throughout the rest of the paper to refer to measurements/sampling made on shallow hand-dug wells (HDWs) during October 2011 and May 2012, respectively. The wells found in the area are typically largediameter (ca. 0.8-1.2 m) HDWs ranging in depths from 3.29 to $9.54 \mathrm{~m}$. All the wells are directly completed in the highly fractured upper portion of the Kızılcadağ ophiolitic mélange and none was identified to have a casing or lining within the saturated zone (Figure 2). These relatively shallow wells are generally equipped with hand pumps and exploited for domestic purposes and/or irrigation water supply, chiefly during summer months. The depth to water in the HDWs $(n=25)$ was determined manually by means of a flat tape water level sounder (Akım Hydrometry, Turkey) with a precision of $1 \mathrm{~mm}$. Water table elevations (with respect to $\mathrm{msl}$ ) were calculated in a Geographic Information System (GIS) environment by subtracting depth to water measurements from the topographic elevations obtained from the digital elevation model (DEM with a grid size of $10 \mathrm{~m}$ ). Groundwater level maps were created by employing the ordinary kriging spatial interpolation algorithm available in the Geostatistical Analyst extension of the ArcGIS 9.3.1 software [64].

3.3. Water Sampling and Analytical Methods. Groundwater samples were collected from identical HDWs $(n=25)$ in dry and wet seasons (Figure 4). In this study, well purging was not attempted due to presence of large volume of water in the HDWs. Groundwater samples were collected from a depth of a few meters below the water table by lowering a plastic bailer into the HDWs. Additionally, snow samples were collected shortly after two major snowfall events on January $2012(n=6)$ and February $2013(n=5)$ from various locations of the site for physicochemical characterization of the precipitation. Sampling and analytical techniques followed the suggestions by APHA-AWWA-WEF [65] and were similar to those described earlier in the literature $[1,66]$. The field parameters ( $\mathrm{pH}$, redox potential (Eh), dissolved oxygen (DO), electrical conductivity (EC), and temperature) were measured in situ using a WTW Multi 340i/SET multiparameter instrument (Wissenschaftlich-Technische Werkstätten, Germany). The probes were calibrated daily in the field using standard procedures before sampling as per manufacturer's instructions. Groundwater samples were immediately filtered on site through a disposable nylon membrane syringe filter (Econofilter) with a pore size of $0.45 \mu \mathrm{m}$ (Agilent Technologies, Germany). In brief, at each site, two $250 \mathrm{~mL}$ aliquots were collected in clean HDPE bottles for cation and anion analyses. Aliquots taken for cation analysis were acidified at the field (below pH 2.0) with 65\% extra pure $\mathrm{HNO}_{3}$ (Merck, Germany) to prevent biological activity and precipitation of cationic species. All the samples were stored in an icebox containing gel-filled ice packs to prevent possible evaporation effects. Then, they were transported to the laboratory and refrigerated at $4^{\circ} \mathrm{C}$ until analysis.

Analyses for total concentrations of five major elements (Ca, Mg, Na, K, and $\mathrm{Si}$ ) and 17 trace elements (Al, As, B, Ba, $\mathrm{Br}, \mathrm{Co}, \mathrm{Cr}, \mathrm{Cu}, \mathrm{Fe}, \mathrm{Li}, \mathrm{Mn}, \mathrm{Mo}, \mathrm{Ni}, \mathrm{Sr}, \mathrm{Ti}, \mathrm{V}$, and $\mathrm{Zn}$ ) in the acidified aliquots were carried out in the MEITAM, Mersin University (Turkey) by Agilent 7500ce ICP-MS (Agilent Technologies, Japan) equipped with Octopole Reaction System. The purity of argon gas used in the ICP-MS was $99.998 \%$ or higher. The external standard calibration method was applied to all determinations using ${ }^{6} \mathrm{Li},{ }^{45} \mathrm{Sc},{ }^{72} \mathrm{Ge},{ }^{89} \mathrm{Y},{ }^{115} \mathrm{In},{ }^{159} \mathrm{~Tb}$, and ${ }^{209} \mathrm{Bi}$ internal standard mix. Five-point calibration curves were created by analyzing NIST single-element reference standards prepared by serial dilution of stock solutions. The concentrations of ammonia $\left(\mathrm{NH}_{4}{ }^{+}\right)$, nitrate $\left(\mathrm{NO}_{3}{ }^{-}\right)$, nitrite $\left(\mathrm{NO}_{2}{ }^{-}\right)$, sulfate $\left(\mathrm{SO}_{4}{ }^{2-}\right)$, orthophosphate $\left(\mathrm{PO}_{4}{ }^{3-}\right)$, chloride $\left(\mathrm{Cl}^{-}\right)$, and fluoride $\left(\mathrm{F}^{-}\right)$in the unacidified aliquots were determined at the Mersin University Geological Engineering Department with Hach Lange DR 2800 spectrophotometer (Hach Lange $\mathrm{GmbH}$, Germany). Carbonate $\left(\mathrm{CO}_{3}{ }^{2-}\right)$ and bicarbonate $\left(\mathrm{HCO}_{3}{ }^{-}\right)$in water samples were determined by volumetric titration with $0.01 \mathrm{~N}$ standard $\mathrm{H}_{2} \mathrm{SO}_{4}$ using phenolphthalein and methyl orange indicator solutions, respectively. The ultrapure water (obtained from the ELGA Purelab UHQ system; Veolia Water Solutions, UK) used in the analytical processes had a resistivity of $18.2 \mathrm{M} \Omega \mathrm{cm}$ at room temperature. The accuracy of the analytical results was 
estimated by calculating the percent charge balance errors (\%CBE), as described by Freeze and Cherry [67]. Calculated $\% \mathrm{CBE}$ average -0.55 for the dry season dataset and -0.30 for the wet season dataset, with standard deviations of 0.86 and 0.40 , respectively. No samples in the database have a $\% \mathrm{CBE}$ greater than \pm 2.31 .

3.4. Statistical Analysis and Data Processing. The water chemistry data were subjected to basic and multivariate statistical analyses utilizing the open source statistical software $\mathrm{R}$ ver. 3.1.2 [68]. The basic statistical analyses include descriptive statistics (minimum, maximum, mean, median, and standard deviation), Pearson product-moment correlation coefficient $(r)$, and Kolmogorov-Smirnov $(\mathrm{K}-\mathrm{S})$ test. $\mathrm{K}-\mathrm{S}$ test $[69,70]$ was used to assess normality of data variables. R-mode factor analysis (R-mFA) was employed for the multivariate statistical analysis of the water chemistry data. R-mFA can help in extraction of hidden information on the factors controlling groundwater chemistry, by only retaining the key components of the dataset. As a data reduction technique, $\mathrm{R}-\mathrm{mFA}$ reduces a large number of variables to a minimum number of uncorrelated (i.e., orthogonal) new variables called factors by linearly combining measurements made on the original variables [71]. Only normalized and standardized variables were utilized in the R-mFA as suggested by Güler et al. [72]. In R-mFA, rotation of factors was carried out using the "varimax raw" method, where Kaiser criterion [73] was utilized to determine the number of factors. Detailed technical description of R-mFA technique and best practices can be found elsewhere [71, 74-77].

The GIS spatial database used in this study was created using (i) $1: 25,000$-scale geological maps published by Alan et al. [36]; (ii) 1:25,000-scale topographic map sheet (Adana M34c3) published by Turkish Ministry of National Defense; (iii) high-resolution $(2.44 \mathrm{~m})$ QuickBird satellite imagery acquired in 2012; and (iv) geographic coordinate measurements made during on-site surveys using a Magellan Triton 2000 GPS unit. The spatial data layers were georeferenced within GIS environment using the WGS84 datum (UTM Zone $36 \mathrm{~N}$ ), then integrated, manipulated, analyzed, and visualized using ArcGIS 9.3.1 software and its extensions, namely, 3D Analyst, Geostatistical Analyst, and Spatial Analyst [64].

3.5. Geochemical Modeling. The geochemical code PHREEQC Interactive ver. 3.1.4 [78] was used for determination of aqueous speciation and saturation indices, as well as for performing inverse modeling calculations related to representative end-member water types. The saturation index (SI) of a mineral phase is defined using

$$
\mathrm{SI}=\log \left(\frac{I A P}{K_{T}}\right),
$$

where IAP is the ion activity product for a given mineral phase and $K_{T}$ is the equilibrium constant of its solubility product at temperature $T$. The SI parameter describes three saturation states. These are (i) undersaturated (SI < 0), (ii) in equilibrium $(\mathrm{SI}=0)$, and (iii) supersaturated $(\mathrm{SI}>0)$ states. All geochemical calculations and water-rock interaction (WRI) modeling were performed using the Lawrence

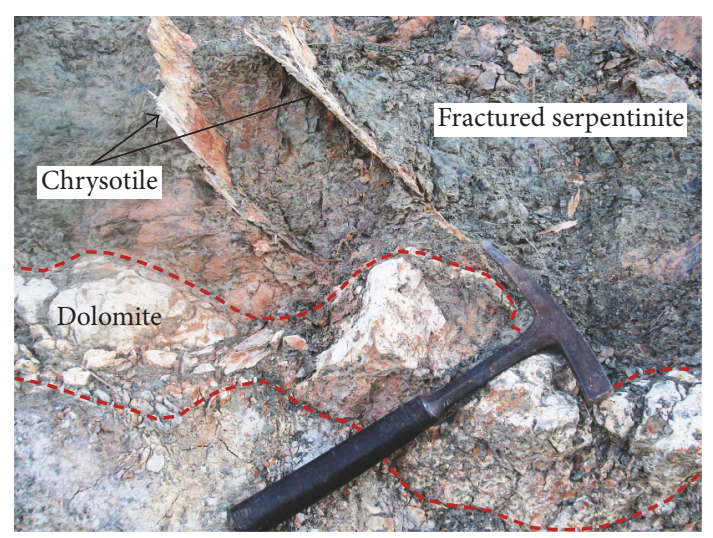

FIGURE 5: Field image of a large fracture system (crosscutting the highly fractured serpentinite rock in Kızılcadağ ophiolitic mélange) filled/sealed with chrysotile (i.e., fibrous asbestos) and secondary dolomite. Hammer for scale is $33 \mathrm{~cm}$ long.

Livermore National Laboratory thermodynamic database, that is, LLNL.dat [79].

\section{Results and Discussion}

4.1. Rock/Soil Mineralogy and Geochemistry. The mineralogical and chemical composition of rocks and soils found in the study area may imprint a unique character to the regional groundwater and will be used to constrain the selection of mineral phases that will be utilized in WRI modeling [80]. Results from XRD analyses (Table 1) were compared with the results from WDXRF analyses (Table 2) to provide a reliable characterization of the mineral phases in the rock and soil samples. XRD analysis of serpentinite rocks making up the Kizılcadağ ophiolitic mélange (i.e., samples R1, R2, and R3) revealed that lizardite is the dominant mineral phase with trace amounts of antigorite, olivine, chromite, calcite, and phlogopite (Table 1), whereas XRD analysis of exotic blocks (i.e., samples R7, R8, and R9) dispersed in the ophiolitic mélange shows the presence of four predominant mineral phases, such as lizardite, quartz, calcite, and dolomite (Table 1). These exotic blocks (i.e., limestone, siltstone, and sandstone) are also associated with minor and trace amounts of secondary mineral phases, such as hematite, ankerite, magnesite, dickite, and vermiculite (Table 1). As reflected in XRD results, carbonate rocks of the Early-Middle Miocene Kaplankaya and Karaisalı formations (samples R4 and R5, resp.) are composed almost entirely of calcite, whereas those of Late Triassic-Early Jurassic Etekli formation (sample R6) are composed predominantly of calcite, with trace amounts of dolomite. Chrysotile (i.e., fibrous asbestos) is the most common mineral phase found in veins and shear zones crosscutting the serpentinite rocks (Figure 5), along with dolomite and trace amounts of clinochlore (i.e., sample R10). In the study area, dolomite mostly occurs as white to pink veins which show fracture-seal texture (Figure 5). Note that sampling of chrysotile veins was intentionally avoided due to hazardous nature of this mineral; therefore, chrysotile was not detected in the XRD analysis. 
TABLE 1: Mineralogical composition of the selected rock (R1-R10) and soil (S1-S8) samples from the Kizllgedik area as determined by X-ray diffraction (XRD) analysis ${ }^{\mathrm{a}}$.

\begin{tabular}{|c|c|c|c|c|c|c|c|c|c|c|c|c|c|c|c|c|c|c|}
\hline Sample number & Lithology $^{b}$ & Source $^{c}$ & $\mathrm{Lz}$ & Atg & $\mathrm{Ol}$ & Qz & Chr & $\mathrm{Cal}$ & Dol & Ank & Mgs & Hem & Dck & Kln & Vrm & $\mathrm{Clc}$ & Di & Phl \\
\hline $\mathrm{R} 1$ & $\mathrm{Kkm}$ & Serpentinite & +++ & + & & & & + & & & & & & & & & & + \\
\hline $\mathrm{R} 2$ & $\mathrm{Kkm}$ & Serpentinite & +++ & & & & + & & & & & & & & & & & \\
\hline R3 & $\mathrm{Kkm}$ & Serpentinite & +++ & & + & & & & & & & & & & & & & \\
\hline R4 & Tkp & Limestone & & & & & & +++ & & & & & & & & & & \\
\hline R5 & Tka & Limestone & & & & & & +++ & & & & & & & & & & \\
\hline R6 & TRJe & Limestone & & & & & & +++ & + & & & & & & & & & \\
\hline R7 & $\mathrm{Kkm}$ & Exotic block & & & & & & +++ & & & & & & & & & & \\
\hline $\mathrm{R} 8$ & $\mathrm{Kkm}$ & Exotic block & ++ & & & & & ++ & +++ & + & + & & + & & & & & \\
\hline R9 & $\mathrm{Kkm}$ & Exotic block & +++ & & & +++ & & & & & & ++ & & & + & & & \\
\hline R10 & $\mathrm{Kkm}$ & Fracture fill & & & & & & & +++ & & & & & & & + & & \\
\hline S1 & $\mathrm{Kkm}$ & Serpentinite & ++ & + & & ++ & & & & & & ++ & & + & + & + & + & \\
\hline S2 & $\mathrm{Kkm}$ & Serpentinite & & +++ & & + & & & & & & & & & ++ & & & \\
\hline S3 & $\mathrm{Kkm}$ & Serpentinite & +++ & +++ & & & & & & & & & & & + & & & \\
\hline S4 & $\mathrm{Kkm}$ & Serpentinite & +++ & & & & & & & & & & & & + & & & \\
\hline S5 & $\mathrm{Kkm}$ & Serpentinite & +++ & & & & & & & & & ++ & & & & & & \\
\hline S6 & $\mathrm{Kkm}$ & Serpentinite & ++ & +++ & & ++ & & & & & & ++ & & + & + & + & & \\
\hline S7 & $\mathrm{Kkm}$ & Serpentinite & +++ & & & & & & & & + & & & & + & & & \\
\hline S8 & $\mathrm{Kkm}$ & Exotic block & & & & + & & ++ & +++ & & & & & & & & & \\
\hline
\end{tabular}

${ }^{\mathrm{a}}$ Abbreviations for names of mineral phases are from Whitney and Evans [85]. Lz $=$ lizardite, $\mathrm{Atg}=$ antigorite, $\mathrm{Ol}=$ olivine, $\mathrm{Qz}=$ quartz, $\mathrm{Chr}=\mathrm{chromite}, \mathrm{Cal}=$ calcite, $\mathrm{Dol}=$ dolomite, Ank = ankerite, $\mathrm{Mgs}=$ magnesite, $\mathrm{Hem}=$ hematite, $\mathrm{Dck}=$ dickite, $\mathrm{Kln}=$ kaolinite, $\mathrm{Vrm}=$ vermiculite, $\mathrm{Clc}=$ clinochlore, $\mathrm{Di}=$ diopside, and $\mathrm{Phl}=$ phlogopite. Pluses indicate relative abundance of mineral phases $(+++=$ major, $++=$ minor, and $+=$ trace $)$ as judged from XRD peak intensities. ${ }^{b}$ Lithology refers to the principal geological formation exposed at the surface in the sampling site (see Figure 3 for geological formation descriptions). ${ }^{\mathrm{c}}$ Source refers to the principal rock type or parent material occurring in the sampling site.

The soils found in the area are generally shallow in depth $(\mathrm{ca} .0-30 \mathrm{~cm})$ and discontinuous and mostly direct weathering product of the serpentinite and carbonate rocks underneath. The mineralogy of serpentinitic soils (samples S1-S7), identified by XRD, was dominated by mineral phases such as lizardite and antigorite (Table 1). In some samples, in addition to these mineral phases, secondary phases such as quartz, hematite, magnesite, kaolinite, vermiculite, clinochlore, and diopside were present (Table 1). The presence of vermiculite and lack of smectites in the upper parts of the soil profiles indicate that soils are well drained and have been formed under temperate climate conditions [81]. Additionally, presence of expansive clays, such as vermiculite, in the soil matrix implies high level of cation exchange capacity $[82,83]$ of serpentinitic soils. On the other hand, a soil sample (i.e., S8) taken from an area overlying an exotic block found within the Kızılcadağ ophiolitic mélange shows the presence of dolomite as the main phase, with lesser amounts of calcite and quartz.

The rock and soil samples were also analyzed by WDXRF technique to reveal their chemical composition (Table 2). Chemical analysis results of serpentinite rocks making up the Kizılcadağ ophiolitic mélange (i.e., samples R1, R2, and R3) show that $\mathrm{SiO}_{2}$ (35.80-38.52 wt.\%) and $\mathrm{MgO}$ (33.03-37.73 wt.\%) are the most abundant oxides, along with $\mathrm{Fe}_{2} \mathrm{O}_{3}$ (9.68-11.03 wt.\%). In these samples, oxides such as $\mathrm{CaO}, \mathrm{MnO}, \mathrm{Al}_{2} \mathrm{O}_{3}, \mathrm{TiO}_{2}$, and $\mathrm{K}_{2} \mathrm{O}$ show relatively low but highly variable concentrations. Serpentinite rocks also contain high concentrations of $\mathrm{Cr}(1864-2982 \mathrm{ppm})$ and $\mathrm{Ni}$
(2487-3857 ppm) (Table 2), which is typical of ultramafic rocks found in the area (see [84]), whereas WDXRF analysis results of exotic blocks (i.e., samples R7, R8, and R9) dispersed in the ophiolitic mélange are characterized by highly variable amounts of oxides (Table 2), as they are composed of different lithologic units (i.e., limestone, siltstone, and sandstone).

The samples R4, R5, R6, and R7 (all limestone formations) composed almost entirely of calcite (Table 1) are found to be low in $\mathrm{SiO}_{2}, \mathrm{Al}_{2} \mathrm{O}_{3}, \mathrm{Fe}_{2} \mathrm{O}_{3}, \mathrm{MnO}, \mathrm{MgO}, \mathrm{K}_{2} \mathrm{O}, \mathrm{P}_{2} \mathrm{O}_{5}$, and $\mathrm{SO}_{3}$ and high in $\mathrm{CaO}$ (59.39-70.86 wt.\%) (Table 2). The sample taken from a fracture fill material (R10), determined by XRD to have dolomite as the major mineral phase (Table 1), is characterized by high $\mathrm{CaO}$ (34.97 wt.\%) and $\mathrm{MgO}$ (15.99 wt.\%) concentrations (Table 2). As reflected by WDXRF analysis, serpentine soils (samples S1-S7) show very similar major oxide compositions, which depleted in $\mathrm{CaO}, \mathrm{K}_{2} \mathrm{O}, \mathrm{MnO}$, $\mathrm{TiO}_{2}, \mathrm{Na}_{2} \mathrm{O}, \mathrm{P}_{2} \mathrm{O}_{5}$, and $\mathrm{SO}_{3}$, and contain high levels of $\mathrm{SiO}_{2}, \mathrm{MgO}, \mathrm{Fe}_{2} \mathrm{O}_{3}$, and $\mathrm{Al}_{2} \mathrm{O}_{3}$ and are enriched in trace elements such as $\mathrm{Cr}$ (1647-11603 ppm) and $\mathrm{Ni}$ (2615-6493 ppm) (Table 2). The distinct differences in $\mathrm{Cr}$ and $\mathrm{Ni}$ concentrations between soils can be taken as an indication of differences in degree of weathering and/or mineralogical compositions of the parent rocks $[83,86]$. Cr most commonly occurs as an accessory mineral (e.g., chromite) in serpentinites, whereas $\mathrm{Ni}$ primarily exists as impurity on the crystal structure of mineral phases in serpentine $[87,88]$. On the other hand, S8 sample, determined by XRD to contain dolomite, calcite, and quartz (Table 1), shows high concentrations of $\mathrm{CaO}, \mathrm{MgO}$, and $\mathrm{SiO}_{2}$ (Table 2), confirming the presence of these mineral 


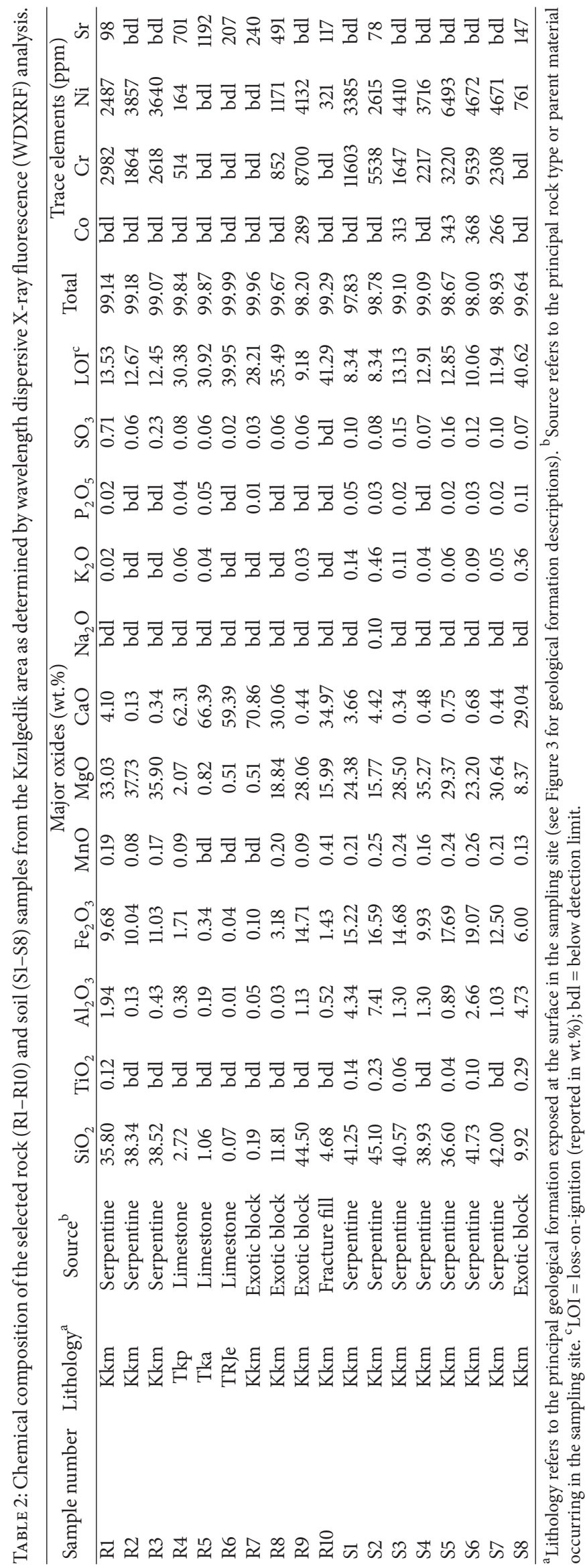


phases. The concentrations of oxides such as $\mathrm{Na}_{2} \mathrm{O}, \mathrm{K}_{2} \mathrm{O}$, $\mathrm{P}_{2} \mathrm{O}_{5}$, and $\mathrm{SO}_{3}$ are generally very low $(<0.10 \mathrm{wt}$.\%) in all types of rock and soil samples (Table 2 ), reflecting the nutrientpoor character of the serpentinitic terrain. The results from XRD and WDXRF analyses suggest that occurrence of mineral phases and elevated concentrations of some elements in the soils of the study area is mostly due to geogenic sources and representative of the geological formations occurring in the area.

4.2. Groundwater Levels and Flow Directions. Water level maps for dry season and wet season are presented in Figures $4(\mathrm{a})$ and 4(b), where average depths to groundwater were 4.83 and $2.79 \mathrm{~m}$ below ground surface (bgs), respectively. The decrease in average depth to water (2.04 $\mathrm{m}$ bgs) between dry season and wet season can be attributed to increased recharge through precipitation, as well as snowmelt, and insignificant amount of groundwater extraction during the off-season (September to May). Even though the groundwater levels in individual HDWs show significant fluctuations (from 0.74 to $5.31 \mathrm{~m}$ ) between dry season and wet season, no discernible spatiotemporal variations were observed on groundwater flow directions and gradients (Figures 4(a) and 4(b)). Equipotential maps constructed for the ophiolitic complex aquifer indicate the direction of the groundwater movement to be mainly from $\mathrm{N}$ to NE/SE near well K2 and from SW to NE near well K6 (Figures 4(a) and 4(b)), both of which are located near the local recharge areas. The hydraulic gradients calculated from equipotential maps vary between $0.047-0.235 \mathrm{~m} / \mathrm{m}$ for dry season and $0.043-0.223 \mathrm{~m} / \mathrm{m}$ for the wet season, showing no significant seasonal gradient changes in the study area. Steep hydraulic gradients are restricted to the SW mountainous part (near well K6), where highly fractured Kizllcadağ ophiolitic mélange is overlain by relatively thin $(\sim 3 \mathrm{~m})$ and low hydraulic conductivity aquitard (i.e., Kaplankaya formation) composed of shallow marine marl, claystone, sandstone, and sandy limestone (Figures 4(a) and 4(b)). An interesting feature in the area is the depression cone formed around well K14, where most of the upgradient flow appears to be directed towards the depression (during both dry and wet seasons), even though no heavy pumping of groundwater ever occurred in or near this well. The depth to water in well K14 was recorded as 5.22 and $3.49 \mathrm{~m}$ bgs in dry season and wet season, respectively. Well K14 is located near $(\sim 60 \mathrm{~m})$ a major fault zone juxtaposing Kizılcadağ ophiolitic mélange and carbonate rocks of Etekli formation (Figures 4(a) and 4(b)), where open fractures and karstic features developed within these units might have collectively provided highly conductive pathways for subsurface outflow underneath the adjacent dry valley. Interestingly, the same fault zone acts as a flow barrier at SW part of the study area, as evidenced by groundwater flow direction that is aligned parallel to the fault zone, displaying a combined conduitbarrier behavior (e.g., see [89]).

4.3. Hydrochemical Characteristics of the Water Samples. The summary statistics of the seasonal physicochemical composition of groundwater and snow samples are presented in Table 3 and complete dataset is provided as supporting information in Table A.1 (Supplementary Material available online at https://doi.org/10.1155/2017/3153924). The average electrical conductivity (EC) values and total dissolved solids (TDS) contents of shallow groundwater are $419 \mu \mathrm{S} \mathrm{cm}^{-1}$ and $288.2 \mathrm{mg} \mathrm{L}^{-1}$ in dry season, whereas the average values of these parameters decline over $10 \%$ and $28 \%$ in wet season, respectively (Table 3 ). Dissolved oxygen (DO) and redox potential (Eh) measurements indicate predominantly oxidizing conditions during both dry and wet seasons, with a tendency towards slightly reducing conditions in dry season (Table 3 ). The $\mathrm{pH}$ values vary from 7.9 to 9.4 in dry season and from 7.4 to 9.3 in wet season (Table 3 ), indicating the slightly to very alkaline nature of the groundwater. The $\mathrm{pH}$ values display somewhat lower values in wet season due to supply of low $\mathrm{pH}$ recharge water from rain and snowmelt (e.g., mean snow $\mathrm{pH}=5.78$ ). Groundwater temperature of shallow HDWs vary slightly (depending on the depth to water) and range from 12.6 to $20.2^{\circ} \mathrm{C}$ in dry season and from 11.0 to $16.6^{\circ} \mathrm{C}$ in wet season (Table 3 ).

In the ophiolitic complex aquifer, a significant seasonal variation in groundwater trace element and major ion chemistry is evident from the summary statistics (Table 3). Generally speaking, the concentration values were higher in the dry season than in the wet season (except for $\mathrm{Ca}^{2+}$, $\mathrm{Cl}^{-}, \mathrm{PO}_{4}{ }^{3-}, \mathrm{Br}$, and $\mathrm{Cr}$ ), indicating relatively rapid recharge from precipitation events. At this site, trace elements could be divided into low ( $<1.0 \mu \mathrm{gL}^{-1}$; Co, Mo, Cu, V, and As), moderate $\left(1.0-10 \mu \mathrm{gL}^{-1} ; \mathrm{Ba}, \mathrm{Cr}, \mathrm{Li}, \mathrm{Ni}\right.$, and $\left.\mathrm{Mn}\right)$, and high $\left(>10 \mu \mathrm{g} \mathrm{L}^{-1} ; \mathrm{Zn}, \mathrm{Al}, \mathrm{B}, \mathrm{Sr}, \mathrm{Ti}, \mathrm{Br}\right.$, and $\mathrm{Fe}$ ) concentration ranges according to their average abundances in the shallow groundwater, considering the entire dataset (e.g., combined dry and wet season samples). The relative abundance of trace elements was ranked (considering median concentrations) in the order $\mathrm{B}>\mathrm{Fe}>\mathrm{Ti}>\mathrm{Br}>\mathrm{Sr}>\mathrm{Zn}>\mathrm{Al}>\mathrm{Li}>$ $\mathrm{Ba}>\mathrm{Ni}>\mathrm{Mn}>\mathrm{Cr}>\mathrm{As}>\mathrm{Mo}>\mathrm{V}>\mathrm{Cu}>\mathrm{Co}$ for dry season samples, whereas they ranked in the order $\mathrm{Br}>\mathrm{Sr}$ $>\mathrm{Ti}>\mathrm{B}>\mathrm{Al}>\mathrm{Zn}>\mathrm{Fe}>\mathrm{Ni}>\mathrm{Cr}>\mathrm{Li}>\mathrm{Ba}>\mathrm{As}>\mathrm{V}$ $>\mathrm{Cu}>\mathrm{Mn}>\mathrm{Co}>\mathrm{Mo}$ for wet season samples (Table 3). The concentrations of major cations and anions found in dry season and wet season groundwater samples (along with mean snow composition) are plotted on the Piper diagram [90] in order to determine main water types and depict the hydrogeochemical evolution path (Figure 6). From this figure, it is evident that the dominant ions in all samples are $\mathrm{Mg}^{2+}, \mathrm{Ca}^{2+}$, and $\mathrm{HCO}_{3}{ }^{-}$, which is typical of ophiolitic and carbonate terrains [91, 92]. Nevertheless, many of the groundwater samples contained very low $\mathrm{Na}^{+}, \mathrm{Cl}^{-}$, and $\mathrm{SO}_{4}{ }^{-2}$ concentrations, both in dry and wet seasons (see Table A.1) (Supplementary Material).

Based on Piper diagram, three hydrochemical facies have been identified, including $\mathrm{Mg}-\mathrm{HCO}_{3}, \mathrm{Mg}-\mathrm{Ca}-\mathrm{HCO}_{3}$, and $\mathrm{Ca}-\mathrm{Mg}-\mathrm{HCO}_{3}$ (Figure 6). About $72 \%$ and $40 \%$ of groundwater samples from dry season and wet season, respectively, belong to $\mathrm{Mg}-\mathrm{HCO}_{3}$ type. The rest of the groundwater samples were mostly classified as $\mathrm{Mg}-\mathrm{Ca}-\mathrm{HCO}_{3}$ type, except for two wet season samples (e.g., K7 and K16), which were classified as $\mathrm{Ca}-\mathrm{Mg}-\mathrm{HCO}_{3}$ type. The linear scattering of the wet season water samples along the $\mathrm{Ca}-\mathrm{Mg}$ axis in the 
TABLE 3: Summary of seasonal physicochemical composition of groundwater (from identical hand-dug wells; $n=25)$ and snow $(n=11$ ) samples collected in the study area.

\begin{tabular}{|c|c|c|c|c|c|c|c|c|c|c|c|c|}
\hline \multirow{2}{*}{ Parameter } & \multirow{2}{*}{ Unit } & \multicolumn{5}{|c|}{ Groundwater (dry season, October 2011) } & \multicolumn{5}{|c|}{ Groundwater (wet season, May 2012) } & \multirow{2}{*}{$\begin{array}{l}\text { Snow }^{\mathrm{d}} \\
\text { Mean }\end{array}$} \\
\hline & & Min & $\operatorname{Max}$ & Mean & Med & SD & Min & Max & Mean & Med & SD & \\
\hline $\mathrm{EC}^{\mathrm{a}}$ & $\mu \mathrm{S} \mathrm{cm}^{-1}$ & 301 & 621 & 419 & 395 & 79.2 & 256 & 556 & 377 & 369 & 71.9 & 8.2 \\
\hline $\mathrm{TDS}^{\mathrm{b}}$ & $\mathrm{mg} \mathrm{L}^{-1}$ & 207.2 & 432.3 & 288.2 & 269.9 & 62.7 & 136.5 & 336.1 & 207.1 & 195.6 & 51.6 & 3.76 \\
\hline $\mathrm{DO}^{\mathrm{c}}$ & $\mathrm{mg} \mathrm{L}^{-1}$ & 2.1 & 6.2 & 4.6 & 4.9 & 1.0 & 3.2 & 8.9 & 5.4 & 5.4 & 1.2 & - \\
\hline $\mathrm{pH}$ & & 7.9 & 9.4 & 8.7 & 8.8 & 0.5 & 7.4 & 9.3 & 8.2 & 8.1 & 0.4 & 5.78 \\
\hline $\mathrm{Eh}$ & $\mathrm{mV}$ & -141 & -59 & -102 & -102 & 26.1 & -145 & -35 & -80 & -76 & 21.7 & 58 \\
\hline Temp. & ${ }^{\circ} \mathrm{C}$ & 12.6 & 20.2 & 16.3 & 16.1 & 1.8 & 11.0 & 16.6 & 13.8 & 13.7 & 1.2 & 4.0 \\
\hline $\mathrm{Ca}^{2+}$ & $\mathrm{mg} \mathrm{L}^{-1}$ & 2.4 & 32.1 & 11.7 & 8.9 & 9.1 & 2.3 & 47.7 & 20.2 & 18.0 & 12.5 & 0.507 \\
\hline $\mathrm{Mg}^{2+}$ & $\mathrm{mg} \mathrm{L}^{-1}$ & 33.1 & 69.8 & 49.5 & 48.7 & 9.3 & 15.9 & 46.6 & 27.3 & 26.7 & 6.9 & 0.058 \\
\hline $\mathrm{Na}^{+}$ & $\mathrm{mg} \mathrm{L}^{-1}$ & 1.6 & 17.9 & 3.1 & 2.4 & 3.2 & 1.0 & 4.3 & 2.0 & 1.8 & 0.8 & 0.224 \\
\hline $\mathrm{K}^{+}$ & $\mathrm{mg} \mathrm{L}^{-1}$ & 0.2 & 4.0 & 0.9 & 0.7 & 0.8 & 0.1 & 1.2 & 0.3 & 0.3 & 0.2 & 0.112 \\
\hline $\mathrm{Si}$ & $\mathrm{mg} \mathrm{L}^{-1}$ & 0.6 & 10.9 & 4.9 & 4.2 & 3.4 & 0.3 & 4.8 & 3.1 & 3.2 & 1.0 & 0.052 \\
\hline $\mathrm{Cl}^{-}$ & $\mathrm{mg} \mathrm{L}^{-1}$ & 0.2 & 5.4 & 2.4 & 2.4 & 1.5 & 2.0 & 7.0 & 3.7 & 3.5 & 1.4 & 0.213 \\
\hline $\mathrm{SO}_{4}{ }^{2-}$ & $\mathrm{mg} \mathrm{L}^{-1}$ & 0 & 11.0 & 1.7 & 1.0 & 2.9 & 0 & 7.0 & 0.9 & 0 & 1.8 & 0.494 \\
\hline $\mathrm{HCO}_{3}{ }^{-}$ & $\mathrm{mg} \mathrm{L}^{-1}$ & 113.1 & 320.4 & 195.3 & 181.8 & 53.8 & 94.7 & 244.1 & 142.8 & 132.0 & 41.2 & 1.512 \\
\hline $\mathrm{CO}_{3}{ }^{2-}$ & $\mathrm{mg} \mathrm{L}^{-1}$ & 2.9 & 32.8 & 14.2 & 11.3 & 9.6 & 0.4 & 19.6 & 2.6 & 1.7 & 3.7 & 0 \\
\hline $\mathrm{F}^{-}$ & $\mathrm{mg} \mathrm{L}^{-1}$ & 0 & 0.8 & 0.08 & 0.02 & 0.16 & 0 & 0.15 & 0.05 & 0.06 & 0.04 & 0.049 \\
\hline $\mathrm{NO}_{3}^{-}$ & $\mathrm{mg} \mathrm{L}^{-1}$ & 0.7 & 9.8 & 3.7 & 3.3 & 2.4 & 0.7 & 7.2 & 3.5 & 3.1 & 1.9 & 0.307 \\
\hline $\mathrm{NO}_{2}^{-}$ & $\mathrm{mg} \mathrm{L}^{-1}$ & 0 & 0.7 & 0.05 & 0.01 & 0.13 & 0 & 0.2 & 0.02 & 0.01 & 0.04 & - \\
\hline $\mathrm{NH}_{4}^{+}$ & $\mathrm{mg} \mathrm{L}^{-1}$ & 0 & 4.2 & 0.3 & 0 & 0.9 & 0 & 0.1 & 0.01 & 0 & 0.02 & 0.140 \\
\hline $\mathrm{PO}_{4}{ }^{3-}$ & $\mathrm{mg} \mathrm{L}^{-1}$ & 0 & 0.12 & 0.02 & 0 & 0.04 & 0 & 12.0 & 0.5 & 0 & 2.4 & 0.045 \\
\hline $\mathrm{Al}$ & $\mu \mathrm{g} \mathrm{L}^{-1}$ & 3.1 & 221.8 & 21.9 & 9.1 & 43.7 & 2.5 & 28.8 & 8.2 & 5.6 & 7.3 & 16.0 \\
\hline As & $\mu \mathrm{g} \mathrm{L}^{-1}$ & 0.9 & 1.7 & 0.9 & 0.9 & 0.2 & 0.1 & 0.9 & 0.5 & 0.5 & 0.3 & 0.1 \\
\hline B & $\mu \mathrm{g} \mathrm{L}^{-1}$ & 13.7 & 58.0 & 30.5 & 29.4 & 12.5 & 4.8 & 30.9 & 13.0 & 12.6 & 6.4 & 1.2 \\
\hline $\mathrm{Ba}$ & $\mu \mathrm{g} \mathrm{L}^{-1}$ & 0.4 & 5.8 & 1.5 & 1.3 & 1.2 & 0.1 & 3.4 & 1.0 & 0.8 & 0.8 & 1.0 \\
\hline $\mathrm{Br}$ & $\mu \mathrm{g} \mathrm{L}^{-1}$ & 20.3 & 37.8 & 26.6 & 25.5 & 4.4 & 25.9 & 37.9 & 31.0 & 30.9 & 2.8 & 1.1 \\
\hline Co & $\mu \mathrm{g} \mathrm{L}^{-1}$ & 0 & 3.9 & 0.3 & 0 & 0.8 & 0 & 0.4 & 0.01 & 0 & 0.07 & 0.1 \\
\hline $\mathrm{Cr}$ & $\mu \mathrm{g} \mathrm{L}^{-1}$ & 0 & 11.3 & 2.8 & 1.8 & 3.2 & 1.6 & 6.8 & 3.5 & 3.4 & 1.4 & 0.3 \\
\hline $\mathrm{Cu}$ & $\mu \mathrm{g} \mathrm{L}^{-1}$ & 0 & 1.5 & 0.5 & 0.3 & 0.5 & 0.01 & 1.1 & 0.4 & 0.3 & 0.3 & 0.3 \\
\hline $\mathrm{Fe}$ & $\mu \mathrm{g} \mathrm{L}^{-1}$ & 0 & 1018 & 88.8 & 28.9 & 201.1 & 0 & 75.4 & 13.0 & 4.3 & 19.4 & 3.0 \\
\hline $\mathrm{Li}$ & $\mu \mathrm{g} \mathrm{L}^{-1}$ & 4.9 & 6.8 & 5.5 & 5.3 & 0.5 & 0.5 & 2.2 & 1.1 & 1.1 & 0.4 & 0.2 \\
\hline $\mathrm{Mn}$ & $\mu \mathrm{g} \mathrm{L}^{-1}$ & 0.2 & 78.6 & 8.8 & 2.6 & 16.8 & 0 & 4.9 & 0.5 & 0.1 & 1.0 & 0.7 \\
\hline Mo & $\mu \mathrm{g} \mathrm{L}^{-1}$ & 0.6 & 1.3 & 0.8 & 0.7 & 0.1 & 0 & 0.2 & 0.03 & 0 & 0.05 & 0.5 \\
\hline $\mathrm{Ni}$ & $\mu \mathrm{g} \mathrm{L}^{-1}$ & 1.5 & 36.1 & 5.3 & 3.6 & 6.8 & 1.3 & 10.0 & 3.9 & 3.6 & 2.1 & 0.3 \\
\hline $\mathrm{Sr}$ & $\mu \mathrm{g} \mathrm{L}^{-1}$ & 3.3 & 87.6 & 27.1 & 13.2 & 23.5 & 2.1 & 86.9 & 27.0 & 19.2 & 19.9 & 2.4 \\
\hline $\mathrm{Ti}$ & $\mu \mathrm{g} \mathrm{L}^{-1}$ & 8.0 & 83.1 & 33.4 & 25.6 & 24.1 & 6.2 & 40.6 & 21.8 & 18.8 & 11.6 & 1.7 \\
\hline $\mathrm{V}$ & $\mu \mathrm{g} \mathrm{L}^{-1}$ & 0.3 & 3.7 & 0.6 & 0.4 & 0.7 & 0.2 & 1.0 & 0.5 & 0.5 & 0.2 & 0.3 \\
\hline $\mathrm{Zn}$ & $\mu \mathrm{g} \mathrm{L}^{-1}$ & 4.6 & 41.4 & 11.8 & 9.8 & 7.3 & 0.3 & 98.6 & 11.9 & 5.1 & 20.3 & 10.6 \\
\hline
\end{tabular}

${ }^{\mathrm{a}}$ Electrical conductivity. ${ }^{\mathrm{b}}$ Total dissolved solids (calculated as sum of all ions). ${ }^{\mathrm{c}}$ Dissolved oxygen. ${ }^{\mathrm{d}}$ Mean snow chemistry. Snow samples were collected in January $2012(n=6)$ and February $2013(n=5)$; Min = minimum, Max = maximum, Med = median, and SD = standard deviation.

Piper diagram (Figure 6) indicates that during the wet season $\mathrm{Ca}^{2+}$ domination increases, where some of the $\mathrm{Mg}-\mathrm{HCO}_{3}$ type dry season samples (e.g., K2, K4, K5, K8, K10, K13, and $\mathrm{K} 17)$ evolve towards $\mathrm{Mg}-\mathrm{Ca}-\mathrm{HCO}_{3}$ type. The decline in values of EC and TDS (Table 3), together with increased $\mathrm{Ca}^{2+}$ domination in wet season samples (Figure 6) can be explained by a mixing mechanism, where more evolved $\mathrm{Mg}-\mathrm{HCO}_{3}$ type dry season groundwater is diluted with less evolved $\mathrm{Ca}-\mathrm{HCO}_{3}$ type recharge water during the wet season.
Indeed, most of the groundwater samples showing a shift in water type during wet season are found in the SW part of the study area where a local recharge area (i.e., Korum Mountain), dominated by carbonate rocks, provides water to the shallow ophiolitic complex aquifer.

In the study area, dry season groundwater from several HDWs (i.e., K4, K5, K6, K10, K18, and K21) is probably affected by the aerobic denitrification processes mediated by the facultative anaerobes [93], which is evidenced 


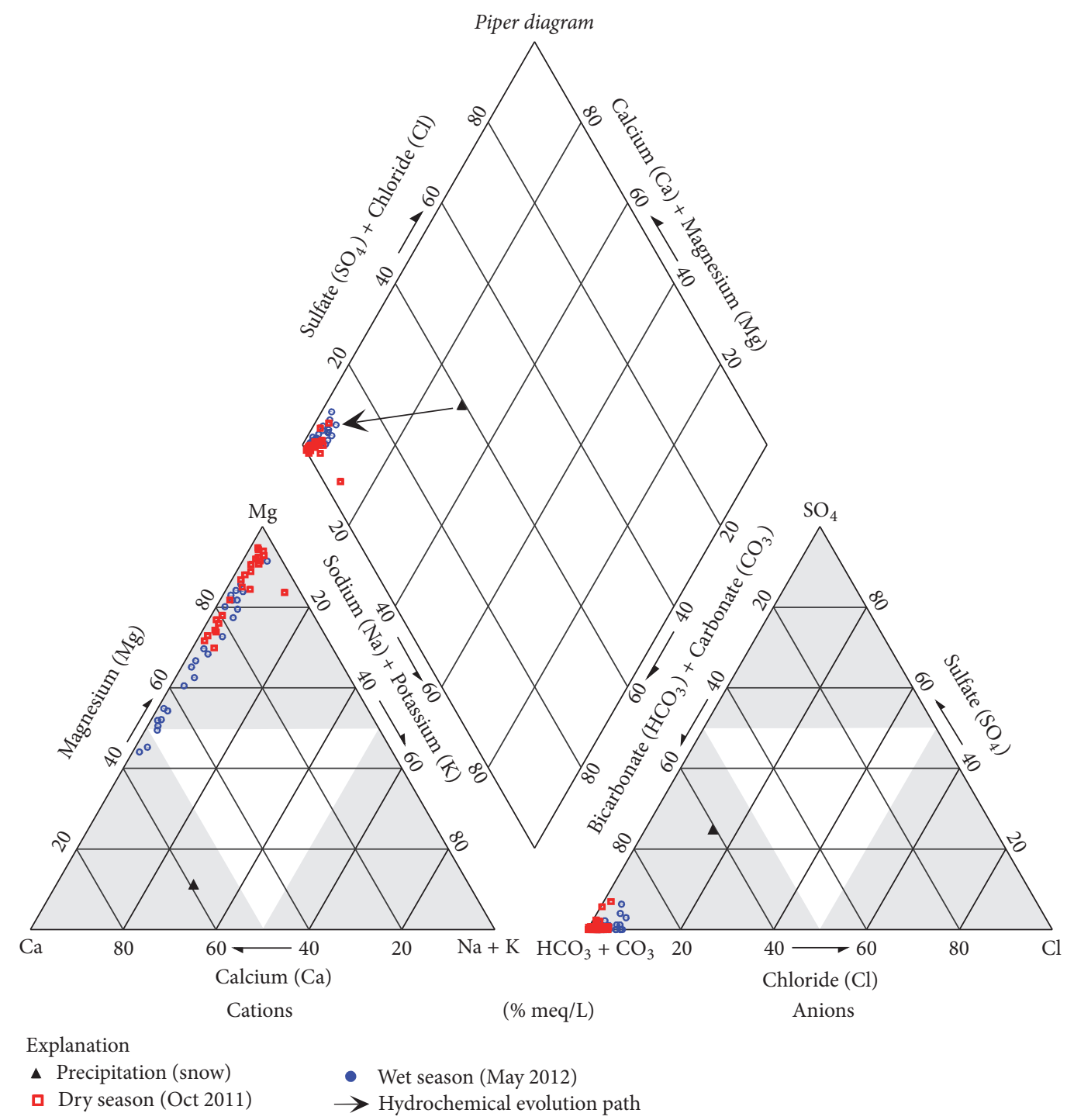

FIGURE 6: Piper diagram [90] showing the major ion composition (in $\% \mathrm{meq}^{-1}$ ) of the groundwater samples collected in dry season $($ October 2011) and wet season (May 2012) from the ophiolitic complex aquifer in the K1zılgedik area. Mean snow chemistry $(n=11)$ of the site represents the starting point in the hydrogeochemical evolution path of groundwater samples.

by their low $\mathrm{NO}_{3}^{-}\left(0.7-6.2 \mathrm{mg} \mathrm{L}^{-1}\right)$ and relatively high DO (2.07-5.46 $\left.\mathrm{mg} \mathrm{L}^{-1}\right)$, Fe $\left(100.7-1018 \mu \mathrm{g} \mathrm{L}^{-1}\right)$, and $\mathrm{Mn}$ (5.76-78.6 $\mu \mathrm{g} \mathrm{L}^{-1}$ ) concentrations (see Table A.1). Fe and Mn are probably mobilized by dissolution of amorphous $\mathrm{Fe} / \mathrm{Mn}$ oxyhydroxides found in the shallow aquifer system and soils. As mentioned previously, Cr displays higher concentrations in wet season than dry season (Table 3 ), which is probably due to low $\mathrm{pH}$ recharge waters reacting with chromite $\left(\mathrm{FeCr}_{2} \mathrm{O}_{4}\right)$, an accessory mineral found in serpentinites (Table 1). In high $\mathrm{pH}$ groundwater (e.g., $\mathrm{pH}>6$ ) $\mathrm{Cr}$ has a low solubility and distributed among various hydroxyl complexes including $\mathrm{CrOH}^{2+}, \mathrm{Cr}(\mathrm{OH})_{2}{ }^{+}$, and $\mathrm{Cr}(\mathrm{OH})_{3}{ }^{0}[94]$.

4.4. Factors Governing the Groundwater Chemistry in the Kizılgedik Area. In the Kizılgedik area, R-mFA multivariate statistical method was utilized in order to explain factors and key processes affecting alkaline groundwater compositions within the ophiolitic complex aquifer. For that purpose, the combined groundwater dataset $(n=50)$ from dry and wet seasons was subjected to R-mFA to account for the observed spatiotemporal variability in water chemistries. K$S$ normality test results showed that the variables $\mathrm{Mg}^{2+}, \mathrm{Na}^{+}$, $\mathrm{Si}, \mathrm{Al}, \mathrm{Fe}, \mathrm{Mn}, \mathrm{Ni}$, and $\mathrm{Sr}$ are log-normally distributed $(p<$ 0.05), while the variables $\mathrm{Ca}^{2+}, \mathrm{Cl}^{-}, \mathrm{HCO}_{3}{ }^{-}$, and $\mathrm{NO}_{3}{ }^{-}$are normally distributed $(p>0.2)$. Therefore, a logarithmic transformation was applied for the variables that display a lognormal distribution. Subsequently, all variables were standardized by calculating their $z$-scores to scale the data to a range of approximately -3 to +3 standard deviations $(\sigma)$, centered about a mean $(\mu)$ of zero [95].

In this study, by applying R-mFA method, 12 variables $\left(\mathrm{Ca}^{2+}, \mathrm{Mg}^{2+}, \mathrm{Na}^{+}, \mathrm{Cl}^{-}, \mathrm{HCO}_{3}{ }^{-}, \mathrm{NO}_{3}{ }^{-}, \mathrm{Si}, \mathrm{Al}, \mathrm{Fe}, \mathrm{Mn}, \mathrm{Ni}\right.$, and 
TABLE 4: Factor loadings for groundwater samples $(n=50)$ of the Kizilgedik area collected during dry and wet seasons. Significant loadings $(>0.700)$ are in bold and underlined (rotation method: varimax raw; extraction method: principal components).

\begin{tabular}{|c|c|c|c|c|c|}
\hline Parameters & Communality $^{\mathrm{a}}$ & Factor 1 & Factor 2 & Factor 3 & Factor 4 \\
\hline $\mathrm{Ca}^{2+}$ & 0.835 & $-\underline{0.854}$ & -0.192 & -0.190 & -0.183 \\
\hline $\mathrm{Mg}^{2+}$ & 0.934 & 0.277 & 0.150 & $\underline{0.913}$ & 0.025 \\
\hline $\mathrm{Na}^{+}$ & 0.851 & 0.137 & -0.036 & 0.533 & $\underline{0.740}$ \\
\hline $\mathrm{Cl}^{-}$ & 0.695 & 0.199 & -0.220 & -0.311 & $\underline{0.714}$ \\
\hline $\mathrm{HCO}_{3}{ }^{-}$ & 0.914 & -0.411 & -0.101 & $\underline{0.853}$ & -0.079 \\
\hline $\mathrm{NO}_{3}^{-}$ & 0.814 & 0.163 & 0.142 & -0.068 & $\underline{0.873}$ \\
\hline $\mathrm{Si}$ & 0.785 & $-\underline{0.817}$ & -0.062 & 0.335 & 0.043 \\
\hline $\mathrm{Al}$ & 0.870 & 0.012 & $\underline{0.926}$ & -0.107 & -0.000 \\
\hline $\mathrm{Fe}$ & 0.857 & 0.138 & $\underline{0.909}$ & 0.101 & 0.032 \\
\hline $\mathrm{Mn}$ & 0.862 & 0.146 & $\underline{0.766}$ & 0.504 & 0.021 \\
\hline $\mathrm{Ni}$ & 0.694 & -0.331 & $\underline{0.746}$ & -0.141 & -0.091 \\
\hline $\mathrm{Sr}$ & 0.913 & $-\underline{0.901}$ & 0.135 & -0.089 & -0.274 \\
\hline Eigenvalue & & 3.321 & 3.077 & 2.261 & 1.364 \\
\hline Cumulative eigenvalue & & 3.321 & 6.398 & 8.659 & 10.023 \\
\hline Explained variance (\%) & & 27.68 & 25.64 & 18.84 & 11.36 \\
\hline Cumulative $\%$ of variance & & 27.68 & 53.32 & 72.16 & 83.52 \\
\hline
\end{tabular}

${ }^{\mathrm{a}}$ The proportion of a variable's variance explained by the factor structure.

Sr) combined to produce four factors explaining $83.52 \%$ of the variance of the original dataset. The remaining factors, explaining only $16.48 \%$ of the data variance, were ignored as "noise," since they do not meet the Kaiser criterion [73]. The orthogonality of the factors was ensured by rotating them using the varimax raw method. The results of the R-mFA are presented in Table 4, where the factors are arranged in decreasing order of importance.

4.4.1. Factor 1: WRI Involving $\mathrm{Ca}$ - and Si-Bearing Phases. Factor 1 explains $27.68 \%$ of the data variance and is mainly associated with the chemical parameters $\mathrm{Ca}^{2+}, \mathrm{Si}$, and $\mathrm{Sr}$ (with loadings $-0.854,-0.817$, and -0.901 , resp.) (Table 4 ). Sources of these chemical parameters may be attributed to naturally occurring WRI processes involving $\mathrm{Ca}$ - and $\mathrm{Si}$ bearing phases (e.g., calcite and quartz), which are known to exist in the formations found at topographically higher recharge zones (e.g., Korum Mountain). Strong association of $\mathrm{Sr}$ with Factor 1 is probably related to its significant concentrations in carbonate rocks. Sr is well known for its association with carbonates such as limestones and dolomites [96], where it can readily substitute for $\mathrm{Ca}^{2+}$ and $\mathrm{Mg}^{2+}$ due to their similar electrochemical behavior. For instance, measured $\mathrm{Sr}$ concentrations in limestone samples (R4 and R5) range between 701 and 1192 ppm, whereas exotic blocks (R7 and R8) dispersed within the ophiolitic mélange display much lower values (i.e., 240 and 491 ppm) (Table 2).

4.4.2. Factor 2: WRI Involving Amorphous Oxyhydroxides and Clay Minerals. The chemical parameters $\mathrm{Al}, \mathrm{Fe}, \mathrm{Mn}$, and $\mathrm{Ni}$ (with loadings $0.926,0.909,0.766$, and 0.746 , resp.) contribute most strongly to the Factor 2 that explains $25.64 \%$ of the data variance (Table 4). The high concentrations of these elements are likely due to WRI processes involving amorphous Fe/Mn oxyhydroxides and clay minerals found in the shallow aquifer system and soils. In such environments, autochthonous microorganisms mediate complex biogeochemical reactions using a number of electron acceptors to decompose organic material [97]. Site specific geochemical data (Table 2) confirm that $\mathrm{Al}, \mathrm{Fe}, \mathrm{Mn}$, and $\mathrm{Ni}$ are abundant in the rock and topsoil samples, where total concentrations (in wt.\%) may reach up to $7.41 \%$ (as $\mathrm{Al}_{2} \mathrm{O}_{3}$ ), $19.07 \%$ (as $\mathrm{Fe}_{2} \mathrm{O}_{3}$ ), $0.41 \%$ (as $\mathrm{MnO}$ ), and $0.83 \%$ (as $\mathrm{NiO}$ ), respectively. In natural groundwater $(\mathrm{pH}<10), \mathrm{Ni}^{2+}$ is preferentially adsorbed onto $\mathrm{Fe}$ (III) and Mn(IV) oxyhydroxides [98], which are possibly present as an amorphous phase or as coatings on grains in the aquifer. The close association between Fe, $\mathrm{Mn}$, and $\mathrm{Ni}$ is a function of their similar atomic radius and high adsorption capacities of Fe/Mn oxyhydroxides [82]. Furthermore, $\mathrm{Fe}^{2+}, \mathrm{Mn}^{2+}$, and $\mathrm{Ni}^{2+}$ may take part in cation exchange processes between the aqueous phase and aquifer materials, considering the abundance of clay minerals in the study area (see Table 1).

4.4.3. Factor 3: WRI Involving Mg-Bearing Phases. Factor 3, explaining $18.84 \%$ of the data variance, displays significant positive loadings ( 0.913 and 0.853 , resp.) on chemical parameters $\mathrm{Mg}^{2+}$ and $\mathrm{HCO}_{3}{ }^{-}$(Table 4). This indicates that the mineralization of groundwater in this area probably occurs through the WRI processes involving Mg-bearing silicates such as serpentine polymorphs (e.g., lizardite, antigorite, and chrysotile), olivine, diopside, and phlogopite and solubility of carbonate minerals (e.g., dolomite). Although the fractured rock aquifer is almost entirely composed of Mg-silicates, no association between $\mathrm{Mg}$ and $\mathrm{Si}$ was evident from the $\mathrm{R}-\mathrm{mFA}$ results (Table 4 ). This lack of association might be explained by the weathering reactions involving serpentine polymorphs, during which either $\mathrm{Mg}^{2+}$ ion is preferentially 


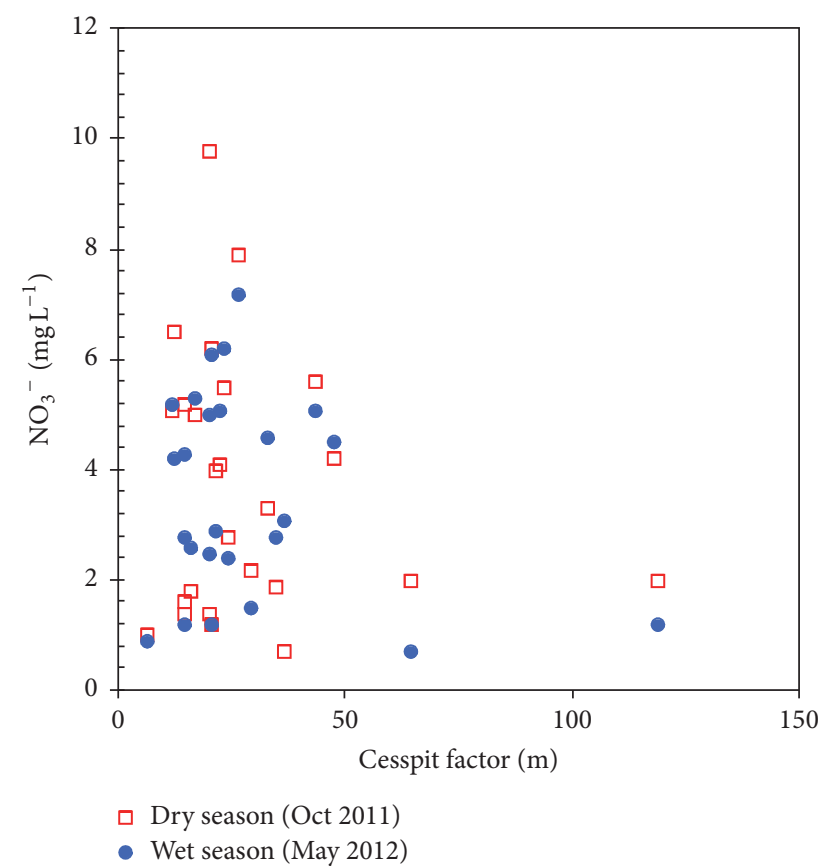

Figure 7: Plot of cesspit factor (Euclidean distance from groundwater sampling site to the nearest pit) versus groundwater nitrate $\left(\mathrm{NO}_{3}{ }^{-}\right)$concentrations in dry and wet seasons. Euclidean distances were calculated using the Spatial Analyst extension of the ArcGIS 9.3.1 software [64].

removed with respect to $\mathrm{Si}^{4+}$ ion or a secondary Si-bearing phase (e.g., quartz or amorphous silica) is precipitated.

4.4.4. Factor 4: Atmospheric and Anthropogenic Inputs. Factor 4 , explaining $11.36 \%$ of the data variance, exhibits significant positive association with $\mathrm{Na}^{+}, \mathrm{Cl}^{-}$, and $\mathrm{NO}_{3}{ }^{-}$(with loadings $0.740,0.714$, and 0.873 , resp.), which are all known to be closely related to dry/wet atmospheric deposition and anthropogenic inputs. In the study site, the substantial amount of these chemical constituents may be derived from the domestic waste (sewage) percolation through cesspits, especially during dry season. However, during wet season, when population is insignificant, dry/wet atmospheric deposition is another process to contribute these constituents to the underlying fractured rock aquifer. In the study area, nitrate concentrations are not well correlated with distance to cesspits. This is depicted in Figure 7, which shows the scatter plot of cesspit factor (Euclidean distance from groundwater sampling site to the nearest pit) versus nitrate concentrations. Aquifer flow is dominated by fractures rather than typical porous media flow meaning that distance may not be good measure. In addition, nitrate will undergo denitrification under aerobic conditions such as those found in the local groundwater (Table 3), making nitrate nonconservative. Thus, direct correlation between nitrate and chloride is not expected unless they have a common source. In fact, nitrate and chloride are not strongly correlated $(r=0.47$ for dry season and $r=0.59$ for wet season) which is consistent with nonconservative nitrate from cesspits and conservative chloride from the dry/wet atmospheric deposition.

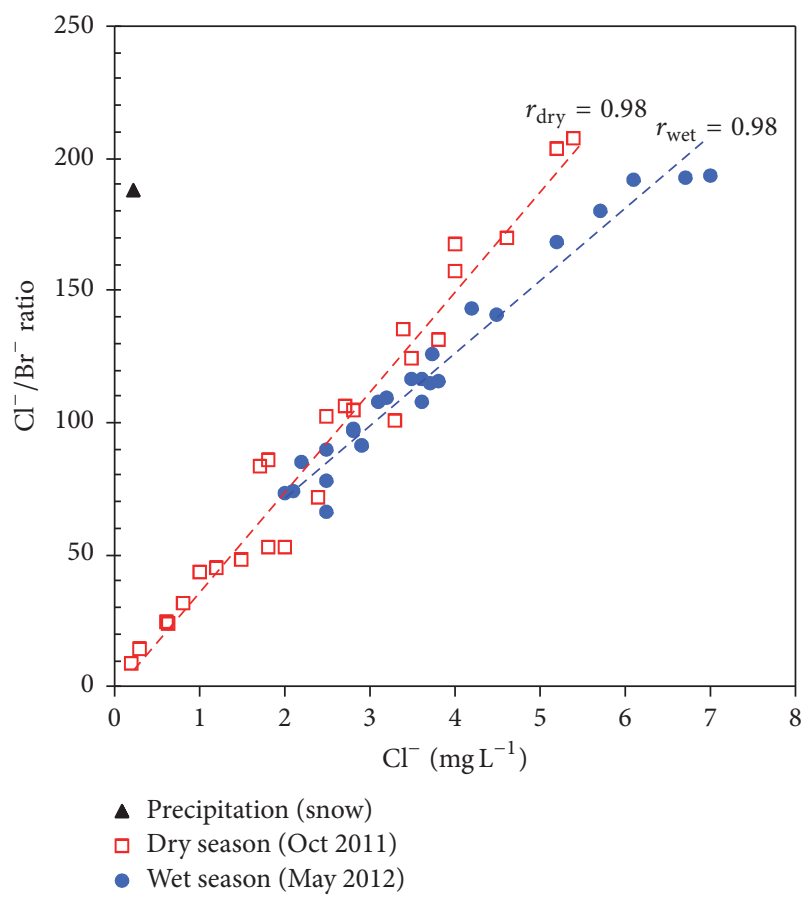

FIGURE 8: Plot of $\mathrm{Cl}^{-}$concentration versus $\mathrm{Cl}^{-} / \mathrm{Br}^{-}$ratio for dry and wet season groundwater samples. Precipitation data reflects the average of 11 snow samples collected from the site on January 2012 $(n=6)$ and February $2013(n=5)$ after two major snowfall events.

The contribution of $\mathrm{Cl}^{-}$from atmospheric deposition can be determined by using the $\mathrm{Cl}^{-} / \mathrm{Br}^{-}$data. The source of salt (i.e., halite) in atmospheric deposition is sea spray. As it can be seen in Figure 8, the $\mathrm{Cl}^{-} / \mathrm{Br}^{-}$ratio is strongly correlated with $\mathrm{Cl}^{-}$for both dry season and wet season $(r=0.98)$ and the ratio values are near seawater (200) or lower. $\mathrm{Cl}^{-} / \mathrm{Br}^{-}$ratios between 50 and 150 are typical of atmospheric precipitation with lower values possible if $\mathrm{Br}^{-}$is preferentially adsorbed on clays [99]. There is no indication of a $\mathrm{Cl}^{-}$source from the cesspits as domestic sewage has $\mathrm{Cl}^{-} / \mathrm{Br}^{-}$ratio between 300 and 600 [99]. Therefore, we conclude that most of the $\mathrm{Cl}^{-}$is derived from atmospheric deposition in the Kızılgedik site.

\subsection{Summary of Spatial and Seasonal Water Chemistry} Variations. In the Kizılgedik site, the overall groundwater chemistry is mostly $\mathrm{Mg}-\mathrm{HCO}_{3}$. As noted in Figure 6, there is some variation with season where the dry season samples are more magnesium rich and the average values for all solutes (except for $\mathrm{Ca}^{2+}, \mathrm{Cl}^{-}, \mathrm{PO}_{4}{ }^{3-}, \mathrm{Br}$, and $\mathrm{Cr}$ ) are higher in the dry season compared to the wet season (see Table 3 ). The arrows in Figure 4 define southern (K6, K7, K8, K17, K15, and K14), central (K3, K19, K11, K12, K13, K14, and K15), and northern (K2, K1, K25, K23, and K24) flow paths. There are variations between wells, but no systematic increase in solutes along flow paths. The larger watershed (to the east, e.g., Korum Mountain) is mainly composed of carbonate rocks (limestone) and karstic in nature. This terrain is expected to generate water chemistry dominated by calcium and bicarbonate. While that signature can explain the $\mathrm{Ca}-\mathrm{HCO}_{3}$ 


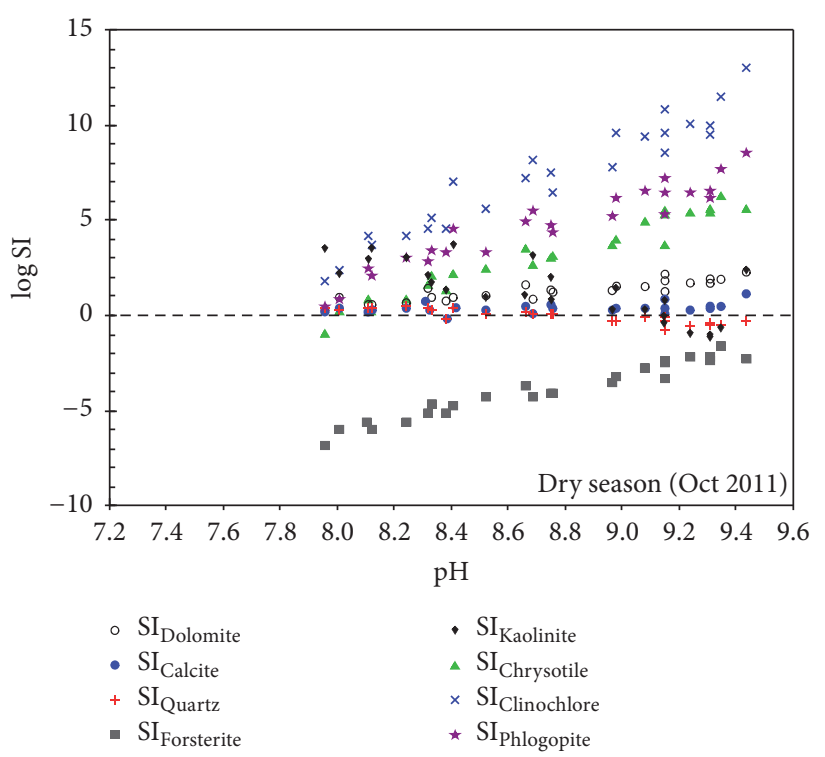

(a)

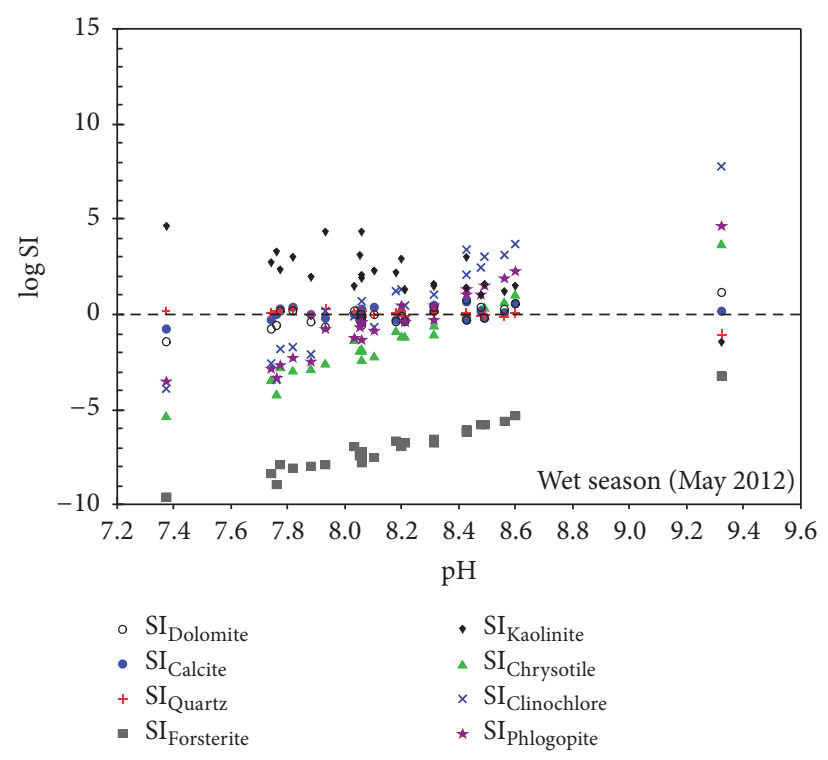

(b)

FIGURE 9: Saturation indices of the (a) dry season and (b) wet season groundwater samples with respect to various primary and secondary mineral phases. Saturation indices were calculated by the geochemical code PHREEQC Interactive ver. 3.1.4 [78] using the accompanying LLNL thermodynamic database [79].

component of the local water chemistry, the magnesium component is clearly from the local serpentinitic mineralogy.

The effect of anthropogenic inputs to the underlying shallow aquifer can be seen in the concentrations of the chemical constituents $\mathrm{NO}_{3}{ }^{-}, \mathrm{NH}_{4}{ }^{+}$, and $\mathrm{NO}_{2}{ }^{-}$(Table A.1). We also see that $\mathrm{Fe}$ and $\mathrm{Mn}$ are elevated in some HDWs located at the central and northern sectors of the study area (i.e., K1, K18, K19, K21, and K25). The increase in concentrations of these constituents is probably due to domestic waste discharges through cesspits during dry season when population drastically increases compared to the off-season. For instance, dry season $\mathrm{NH}_{4}{ }^{+}$concentrations in $\mathrm{Kl}, \mathrm{K} 19$, and K25 (Table A.1) were more than one to eight times the standard value $\left(0.5 \mathrm{mg} \mathrm{L}^{-1}\right)$ set by EC [100]. Additionally, dry season concentrations of $\mathrm{NO}_{2}^{-}$in $\mathrm{K} 1\left(0.68 \mathrm{mg} \mathrm{L}^{-1}\right)$, Fe in $\mathrm{K} 18\left(205.6 \mu \mathrm{g} \mathrm{L}^{-1}\right)$, and $\mathrm{Mn}$ in $\mathrm{K} 21\left(78.6 \mu \mathrm{g} \mathrm{L}^{-1}\right)$ were slightly higher than the EC [100] standards for drinking water. Based on the data, there is limited impact from cesspits to local groundwater chemistry, except for five wells where the standards are exceeded.

4.6. Geochemical Modeling of Water-Rock Interaction (WRI). The geochemical modeling of the WRI starts with the speciation of all water analyses according to the thermodynamic database (e.g., LLNL.dat). All the phases identified in XRD, except vermiculite and lizardite, are found in the database. Nevertheless, the LLNL database did contain antigorite and chrysotile, which are different forms of serpentine. Additionally, generic olivine data was not available, but the LLNL database did contain forsterite, the magnesium endmember of olivine. Therefore, all the identified primary and secondary minerals, except vermiculite, can be included in the model. The data used in the geochemical modeling included temperature, $\mathrm{pH}, \mathrm{Na}, \mathrm{K}, \mathrm{Ca}, \mathrm{Mg}$, alkalinity (as $\left.\mathrm{HCO}_{3}\right), \mathrm{SO}_{4}, \mathrm{Cl}, \mathrm{F}, \mathrm{NO}_{3}, \mathrm{NH}_{4}, \mathrm{Fe}, \mathrm{Mn}, \mathrm{Cr}, \mathrm{Al}, \mathrm{Si}$, and $\mathrm{Sr}$ (Table 3). Other trace elements were not included to simplify the modeling. PHREEQC was used for speciation of all water samples $(n=50)$ and to calculate saturation indices (SI) of selected minerals.

4.6.1. Saturation Data. The saturation indices (SI) of dry season and wet season groundwater samples are shown in Figure 9 for selected primary (i.e., calcite, forsterite, chrysotile, and phlogopite) and secondary (product) minerals (i.e., dolomite, quartz, kaolinite, and clinochlore). Minerals with negative SI values (undersaturated) are likely to dissolve, while minerals with positive SI values (supersaturated) are likely to precipitate.

Calculated SI values for antigorite and chromite (both not shown) are very positive indicating that the minerals would never dissolve or the thermodynamic data are not very accurate. The primary mineral chrysotile is supersaturated during the dry season (mean SI $=3.14$ ) but becomes undersaturated in most water wells during the wet season (mean SI $=-1.47)$ (Figure 9). Olivine (forsterite) is undersaturated in both dry and wet seasons (Figure 9) with average SI values of -3.94 and -7.07 , respectively. Similar to chrysotile, phlogopite is supersaturated during the dry season (mean $\mathrm{SI}=4.74$ ) but becomes undersaturated in many well samples during the wet season (mean SI $=-0.47$ ) (Figure 9). The variation in saturation during the wet season with greater undersaturation for the same sample location is consistent with the dilution of groundwater with recharge lowering TDS and promoting dissolution of primary minerals (weathering). Calcite is close to saturation at most locations during both seasons (mean SI $=0.38$ during dry season and mean 


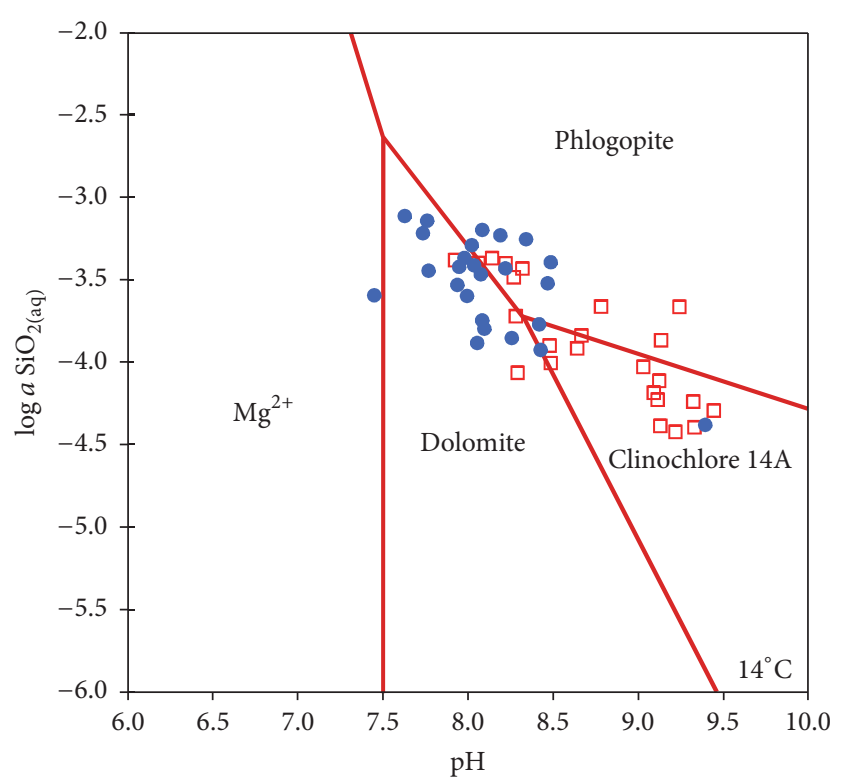

$\square$ Dry season (Oct 2011)

- Wet season (May 2012)

FIGURE 10: Mineral stability diagram for the $\mathrm{MgO}-\mathrm{Al}_{2} \mathrm{O}_{3}-\mathrm{SiO}_{2}-\mathrm{H}_{2} \mathrm{O}$ system. The aqueous silica $\left(\log a \mathrm{SiO}_{2(\mathrm{aq})}\right)$ concentrations versus $\mathrm{pH}$ values for the dry season and wet season groundwater samples are plotted on the diagram using The Geochemist's Workbench ${ }^{\circledR}$ software [101]. Solid lines represent saturation at $14^{\circ} \mathrm{C}$ and 1-bar pressure for the selected mineral phases.

SI $=-0.05$ during wet season) (Figure 9), indicating limited calcite dissolution or precipitation at the site. During the dry season, however, some secondary minerals such as dolomite, clinochlore, and magnesite (not shown) show a strong pattern of supersaturation indicating potential precipitation and lower degree of supersaturation during the wet season, while others such as quartz, kaolinite, and $\mathrm{Fe}(\mathrm{OH})_{3}$ (not shown), are near equilibrium during both seasons (Figure 9).

The saturation indices show the main WRI reactions involve dissolution of forsterite and in some cases during the wet season also of phlogopite and chrysotile, together with dolomite, clinochlore, kaolinite, and quartz precipitation. Dissolved silica concentration appears limited by formation of kaolinite and quartz. This accounts for the lack of (statistical) association between $\mathrm{Mg}$ and $\mathrm{Si}$ in groundwater. While both solutes are supplied from the Mg-silicates, the loss is governed by different minerals with different solubilities. The silica concentration and $\mathrm{pH}$ values for all dry and wet season samples are plotted in Figure 10, the mineral stability diagram for the $\mathrm{MgO}-\mathrm{Al}_{2} \mathrm{O}_{3}-\mathrm{SiO}_{2}-\mathrm{H}_{2} \mathrm{O}$ system. The samples plot on or near the phlogopite-dolomite-clinochlore boundaries as expected based on the saturation indices. This indicates that the major solutes $\mathrm{Mg}^{2+}$ and $\mathrm{HCO}_{3}{ }^{-}$(Factor 3 from R-mFA) may be controlled by water-rock equilibria between these mineral phases.

4.6.2. Inverse Geochemical Modeling. Inverse geochemical modeling is a method to quantify the WRI reactions that produce the observed groundwater chemistry. One solution is defined as the starting point and second solution as the end point. The model calculates the mole transfers of minerals and gases required to produce the second solution using dissolution or precipitation reactions [102].

One set of models used snow (see Table 3 ) as the initial solution and dissolved or precipitated minerals and gases to reach the dry season average water composition (Table 3; models $1-3$ of Table 5). A second set of simulations (models 4-6 of Table 5) start with the dry season average water composition and reach the wet season average composition. Table 5 shows the results of the inverse geochemical modeling where the values are in moles per $\mathrm{kg}$ of water, and positive values indicate dissolution (or ingassing) while negative values indicate precipitation (or outgassing). The models all consume $\mathrm{CO}_{2}$ and $\mathrm{O}_{2}$ and dissolve most the primary minerals (serpentine, olivine, calcite, and chromite) as well as minor amounts of halite. Considering that the site is located $100 \mathrm{~km}$ north of the Mediterranean Sea coastline, the source of halite $(\mathrm{NaCl})$ is most likely the dry/wet atmospheric deposition of sea salt aerosol particles entrained into the atmosphere by wind action at the sea-air interface. Site specific groundwater and snow $\mathrm{Cl}^{-} / \mathrm{Br}^{-}$ratios (Figure 8) together with the lack of a strong correlation between $\mathrm{NO}_{3}{ }^{-}$and $\mathrm{Cl}^{-}$ions suggest that domestic waste discharge from the cesspits is unlikely to be a major source of halite in this seasonally inhabited headwater area. All snow to dry season models need ferrihydroxide, clinochlore, chromium oxide, and quartz precipitation. However, model 1 dissolves chrysotile, but not forsterite to account for the dissolved magnesium, while the other models dissolve forsterite. Models 1 and 2 precipitate dolomite, whereas model 3 does not, as it uptakes less $\mathrm{CO}_{2}$ (Table 5). The two dry to wet season models (models 4 and 5) have the reactant water to account for the dilution effect of recharge (Table 5). Models 4-6 are similar; none have clinochlore or chromium oxide precipitation (there is very little chromite dissolved) but one has dolomite precipitation. Altogether, the models for dry and wet seasons show the major solutes are basically controlled by dissolution of primary minerals and formation of secondary minerals that are observed to be present in the headwater area. Explicitly, the modeling results demonstrated that five reactants or dissolving phases and five products or precipitating phases (see Table 5) are sufficient to explain seasonal differences occurring in groundwater compositions. The difference between dry and wet season groundwater compositions appears to be mostly due to increased influx of water (e.g., recharge from rain and/or snowmelt) during the wet season. However, it should be underlined that the inverse models often provide nonunique solutions, meaning that for any hydrochemical evolution step more than one model is usually found (see Table 5).

In a broad sense, multivariate statistical method used in this study (R-mFA) was able to discern the factors (i.e., Factor 1: WRI involving $\mathrm{Ca}$ - and Si-bearing phases; Factor 2: WRI involving amorphous oxyhydroxides and clay minerals; Factor 3: WRI involving Mg-bearing phases; and Factor 4: atmospheric/anthropogenic inputs) representing major geochemical processes taking place in the groundwater system. This indicates that, as an initial step, R-mFA can be of a great assistance while formulating inverse geochemical 


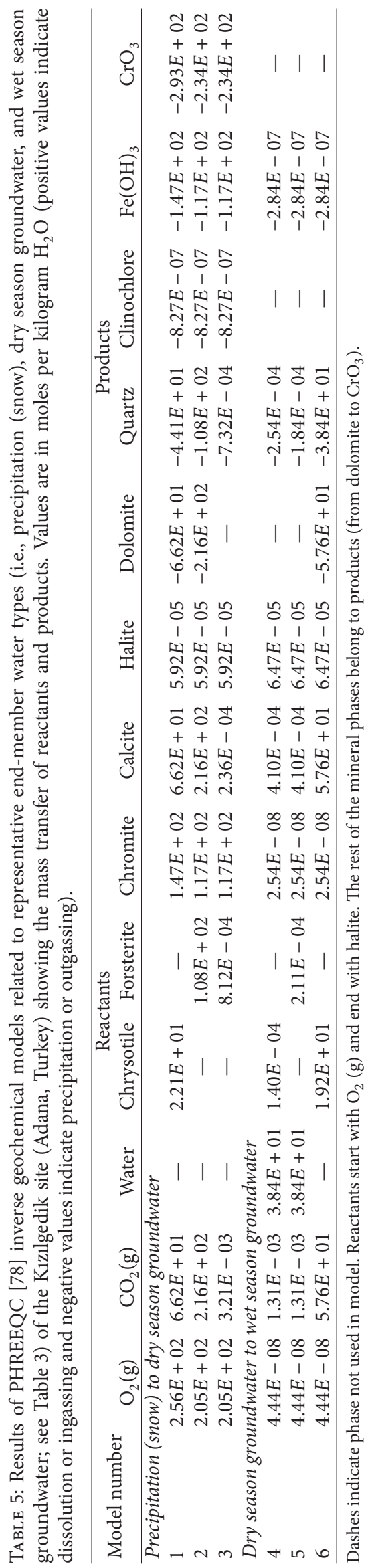


models and deciphering the relative importance of a variety of factors (geologic, hydrologic, topographic, physiographic, climatic, anthropogenic, etc.) influencing groundwater composition. In general terms, the results obtained from saturation index (SI) calculations have shown that saturation states of forsterite, quartz, chromite, and halite in individual groundwater samples do not change drastically between seasons, whereas saturation states of the chrysotile, calcite, dolomite, and clinochlore in individual groundwater samples show significant variations. This indicates that mineral phases found in the headwater area respond differently to the increased influx of recharge during the wet season, which is also reflected in the mass transfer amounts of reactants and products calculated by geochemical models (Table 5 ).

\section{Conclusions}

In this study, graphical, multivariate statistical (e.g., R-mFA), GIS, and PHREEQC inverse geochemical modeling tools were employed to investigate the natural and anthropogenic processes governing the alkaline groundwater chemistry of a seasonally inhabited headwater area located in an alpine environment (Adana, Turkey). Dry season (October 2011) and wet season (May 2012) groundwater samples from shallow hand-dug wells on ophiolitic mélange, as well as snow, rock, and soil samples collected throughout the site, were used to evaluate hydrogeochemical processes occurring in this headwater environment.

Results from the XRD and WDXRF analyses of collected rock and soil samples have shown that major mineral phases found in the area include lizardite, antigorite, calcite, dolomite, and quartz, together with minor amounts of hematite and vermiculite, and trace amounts of clinochlore, magnesite, kaolinite, olivine, chromite, ankerite, dickite, diopside, and phlogopite. In this headwater area, karstic features such as sinkholes, together with faults displaying a combined conduit-barrier behavior, appear to play an important role in controlling groundwater flow patterns and recharge/discharge mechanisms. However, no discernable seasonal differences were observed for hydraulic gradients and groundwater flow directions in the ophiolitic complex aquifer. As illustrated by the Piper diagram, $\mathrm{Mg}-\mathrm{HCO}_{3}$ and $\mathrm{Mg}-\mathrm{Ca}-\mathrm{HCO}_{3}$ water types are prevalent (with $\mathrm{pH}$ values ranging from 7.4 to 9.4), indicating influence of ophiolitic and carbonate rocks on the local groundwater chemistry. The difference between the dry and wet season samples was mainly the dilution of solutes during the recharge period. Results obtained from R-mFA corroborate these results but also point to atmospheric/anthropogenic inputs (e.g., $\mathrm{Na}^{+}, \mathrm{Cl}^{-}$, and $\mathrm{NO}_{3}{ }^{-}$). The PHREEQC inverse geochemical models were used to quantify the processes that affect the groundwater evolution between end-member water types. The results of PHREEQC inverse modeling revealed that the groundwater chemistry is strongly dependent on the local serpentine mineralogy that contains reactive minerals such as lizardite, antigorite, olivine, chromite, calcite, and phlogopite. The major solutes (e.g., $\mathrm{Mg}^{2+}, \mathrm{Ca}^{2+}$, and $\mathrm{HCO}_{3}{ }^{-}$) appear to be the product of water-rock interactions of these minerals and local recharge. The byproducts of the weathering reactions include Fe-oxides, clinochlore, silica, and dolomite, all found in the aquifer. The presence of local mineralization and the near equilibrium between minerals and groundwater within this small watershed imply rapid water-rock reactions. The presence of cesspits that discharge sewage directly into the aquifer does cause local exceedance in drinking water standards for nitrite and ammonia, but nitrate concentrations remained below regulatory standards.

Using a methodology employing these diverse tools can provide an increased understanding of the chemical nature of groundwater, its geochemical evolution, and the influence of spatially and seasonally variable anthropogenic inputs from point sources (i.e., cesspits) in the headwater areas with increased human influence. The results obtained from this study can be used to improve public policies and water quality regulations and to promote sustainable development and effective management of water resources in alpine headwater areas, which are usually considered as nearly pristine and out of human influence. However, continuous monitoring is needed to fully characterize the hydrological and hydrochemical dynamics in the headwater environments, which is currently a neglected research topic throughout much of the world.

\section{Conflicts of Interest}

The authors declare that there are no conflicts of interest regarding the publication of this paper.

\section{Acknowledgments}

Mersin University Scientific Research Projects (BAP) unit funded this study through two separate grants to the senior author (BAP-MÜH F JMB (CG) 2012-2 HD and BAP-MÜH F JMB (CG) 2014-1 HD). The authors wish to thank their former undergraduate students Ali Karakoç, İran Balbay, and Özcan Canpolat for their enthusiastic assistance in both the field and laboratory. They are very grateful to all the landowners for providing access to sampling sites and samples. They are indebted to Dr. Mehmet Ali Kurt from the Advanced Technology Education, Research and Application Center (MEITAM), Mersin University, for XRD, WDXRF, and ICP-MS analyses.

\section{References}

[1] C. Güler, M. A. Kurt, M. Alpaslan, and C. Akbulut, "Assessment of the impact of anthropogenic activities on the groundwater hydrology and chemistry in Tarsus coastal plain (Mersin, SE Turkey) using fuzzy clustering, multivariate statistics and GIS techniques," Journal of Hydrology, vol. 414-415, pp. 435-451, 2012.

[2] R. C. Sidle, Y. Tsuboyama, S. Noguchi, I. Hosoda, M. Fujieda, and T. Shimizu, "Stormflow generation in steep forested headwaters: A linked hydrogeomorphic paradigm," Hydrological Processes, vol. 14, no. 3, pp. 369-385, 2000.

[3] P. Pechan and G. E. de Vries, Living with Water: Targeting Quality in a Dynamic World, Springer-Verlag, New York, NY, 2013. 
[4] L. Benda, M. A. Hassan, M. Church, and C. L. May, "Geomorphology of steepland headwaters: The transition from hillslopes to channels," Journal of the American Water Resources Association, vol. 41, no. 4, pp. 835-851, 2005.

[5] K. Bishop, I. Buffam, M. Erlandsson et al., "Aqua Incognita: The unknown headwaters," Hydrological Processes, vol. 22, no. 8, pp. 1239-1242, 2008.

[6] T. Gomi, R. C. Sidle, and J. S. Richardson, "Understanding processes and downstream linkages of headwater systems," BioScience, vol. 52, no. 10, pp. 905-916, 2002.

[7] M. J. Haigh and J. Křeček, "Headwater management: problems and policies," Land Use Policy, vol. 8, no. 3, pp. 171-176, 1991.

[8] M. L. Paracchini, S. Folving, and F. Bertolo, "Identification and classification of European headwaters," in Environmental Reconstruction in Headwater Areas, M. Haigh and J. Křeček, Eds., pp. 67-79, Kluwer Academic Publishers, Dordrecht, 2000.

[9] J. Křček and M. J. Haigh, "Reviewing the contexts of headwater control," in Environmental Reconstruction in Headwater Areas, M. Haigh and J. Křeček, Eds., pp. 9-24, Kluwer Academic Publishers, Dordrecht, 2000.

[10] B. H. Hill, R. K. Kolka, F. H. McCormick, and M. A. Starry, "A synoptic survey of ecosystem services from headwater catchments in the United States," Ecosystem Services, vol. 7, pp. 106-115, 2014.

[11] R. E. Horton, "Erosional development of streams and their drainage basins; hydrophysical approach to quantitative morphology," Bulletin of the Geological Society of America, vol. 56, no. 3, pp. 275-370, 1945.

[12] A. N. Strahler, "Quantitative analysis of watershed geomorphology," Eos, Transactions American Geophysical Union, vol. 38, no. 6, pp. 913-920, 1957.

[13] R. B. Alexander, E. W. Boyer, R. A. Smith, G. E. Schwarz, and R. B. Moore, "The role of headwater streams in downstream water quality," Journal of the American Water Resources Association, vol. 43, no. 1, pp. 41-59, 2007.

[14] W. K. Dodds and R. M. Oakes, "Headwater influences on downstream water quality," Environmental Management, vol. 41, no. 3, pp. 367-377, 2008.

[15] J. A. Villines, C. T. Agouridis, R. C. Warner, and C. D. Barton, "Using GIS to delineate headwater stream origins in the Appalachian Coalfields of Kentucky," Journal of the American Water Resources Association, vol. 51, no. 6, pp. 1667-1687, 2015.

[16] P. J. Hancock, A. J. Boulton, and W. F. Humphreys, "Aquifers and hyporheic zones: towards an ecological understanding of groundwater," Hydrogeology Journal, vol. 13, no. 1, pp. 98-111, 2005.

[17] J. L. Meyer, D. L. Strayer, J. B. Wallace, S. L. Eggert, G. S. Helfman, and N. E. Leonard, "The contribution of headwater streams to biodiversity in river networks," Journal of the American Water Resources Association, vol. 43, no. 1, pp. 86-103, 2007.

[18] R. Murgai, M. Ali, and D. Byerlee, "Productivity growth and sustainability in post-green revolution agriculture: The case of the Indian and Pakistan Punjabs," World Bank Research Observer, vol. 16, no. 2, pp. 199-218, 2001.

[19] I. Atalay, R. Efe, and M. Öztürk, "Effects of topography and climate on the ecology of Taurus mountains in the Mediterranean region of Turkey," Procedia - Social and Behavioral Sciences, vol. 120, pp. 142-156, 2014.

[20] S. Tüfekçi, A. Savran, Y. Bağc1, and N. Özkurt, "Aladağlar Milli Parkının Florası," Orman Bakanlığı Yayın 206, Mersin, Tarsus, Turkey, 2002 (Turkish).
[21] K. T. Yllmaz, "Ecological diversity of the eastern Mediterranean region of Turkey and its conservation," Biodiversity and Conservation, vol. 7, no. 1, pp. 87-96, 1998.

[22] M. Golge, F. Yenilmez, and A. Aksoy, "Development of pollution indices for the middle section of the Lower Seyhan Basin (Turkey)," Ecological Indicators, vol. 29, pp. 6-17, 2013.

[23] S. Yaşar Korkanç, "Impacts of recreational human trampling on selected soil and vegetation properties of Aladag Natural Park, Turkey," Catena, vol. 113, pp. 219-225, 2014.

[24] I. Atalay, "Land use in the karstic lands in the Mediterranean region," International Journal of Speleology, vol. 28, no. 1, pp. 111$118,1999$.

[25] W. Eberhard, "Nomads and farmers in southeastern Turkey: Problems of settlement," Oriens, vol. 6, no. 1, pp. 32-49, 1953.

[26] O. I. Davutluoglu, G. Seckin, C. B. Ersu, T. Yilmaz, and B. Sari, "Assessment of metal pollution in water and surface sediments of the Seyhan River, Turkey, using different indexes," Clean Soil, Air, Water, vol. 39, no. 2, pp. 185-194, 2011.

[27] F. Evrendilek, I. Celik, and S. Kilic, "Changes in soil organic carbon and other physical soil properties along adjacent Mediterranean forest, grassland, and cropland ecosystems in Turkey," Journal of Arid Environments, vol. 59, no. 4, pp. 743$752,2004$.

[28] E. Toroğlu and E. Ünaldı, "Aladağlar'da (Toros dağları) bitki örtüsünün ekolojik şartları," Fırat Üniversitesi Sosyal Bilimler Dergisi, vol. 18, no. 2, pp. 23-48, 2008 (Turkish).

[29] Y. Fujihara, S. P. Simonovic, F. Topaloğlu, K. Tanaka, and T. Watanabe, "An inverse-modelling approach to assess the impacts of climate change in the Seyhan River basin, Turkey," Hydrological Sciences Journal, vol. 53, no. 6, pp. 1121-1136, 2008.

[30] Y. Fujihara, K. Tanaka, T. Watanabe, T. Nagano, and T. Kojiri, "Assessing the impacts of climate change on the water resources of the Seyhan River Basin in Turkey: Use of dynamically downscaled data for hydrologic simulations," Journal of Hydrology, vol. 353, no. 1-2, pp. 33-48, 2008.

[31] T. Yano, M. Aydin, and T. Haraguchi, "Impact of climate change on irrigation demand and crop growth in a Mediterranean environment of Turkey," Sensors, vol. 7, no. 10, pp. 2297-2315, 2007.

[32] TSMS (Turkish State Meteorological Service), "TÜMAS," http://tumas.mgm.gov.tr/wps/portal/.

[33] N. Özgül, "Stratigraphy and tectonic evolution of the central Taurides," in Proceedings of the International Symposium on the Geology of the Taurus Belt, O. Tekeli and M. C. Göncüoğlu, Eds., pp. 77-90, Maden Tetkik ve Arama Enstitüsü, Ankara, 1984.

[34] N. Jaffey and A. Robertson, "Non-marine sedimentation associated with Oligocene-Recent exhumation and uplift of the Central Taurus Mountains, S Turkey," Sedimentary Geology, vol. 173, no. 1-4, pp. 53-89, 2005.

[35] A. Johannsen, “The serpentines of Harford county," Maryland Geological Survey, vol. 12, pp. 197-287, 1928.

[36] I. Alan, S. Şahin, H. Keskin et al., "Orta Toroslar’ın Jeodinamik Evrimi: Ereğli (Konya)-Ulukışla (Niğde)-Karsantı (Adana)Namrun (İçel) Yöresi," Report 11006, Maden Tetkik ve Arama Genel Müdürlüğü, Ankara, Turkey, 2007 (Turkish).

[37] G. Kelling, A. Robertson, and F. Van Buchem, "Cenozoic sedimentary basins of southern Turkey: An introduction," Sedimentary Geology, vol. 173, no. 1-4, pp. 1-13, 2005.

[38] U. C. Ünlügenç and A. C. Akinci, "Sedimentary development of the Oligocene Karsanti Basin, southern Turkey, in its regional tectonic setting," Journal of Asian Earth Sciences, vol. 105, pp. 173-191, 2015. 
[39] O. Tekeli, A. Aksay, B. M. Ürgün, and A. Işık, "Geology of the Aladag Mountains," in Proceedings of the International Symposium on the Geology of the Taurus Belt, O. Tekeli and M. C. Göncüoğlu, Eds., pp. 143-158, Maden Tetkik ve Arama Enstitüsü, Ankara, 1984.

[40] A. E. Aksu, S. Walsh-Kennedy, J. Hall et al., "The PlioceneQuaternary tectonic evolution of the Cilicia and Adana basins, Eastern Mediterranean: Special reference to the development of the Kozan fault zone," Tectonophysics, vol. 622, pp. 22-43, 2014.

[41] C. Demirkol, "Pozant1-Karsant1-Karaisalı (Doğu Toros) arasinda yer alan karbonat platformunun stratigrafisi ve jeolojik gelişimi," Maden Tetkik ve Arama Enstitüsü Dergisi, vol. 109, pp. 33-44, 1989 (Turkish).

[42] A. Ilgar, W. Nemec, A. Hakyemez, and E. Karakuş, "Messinian forced regressions in the Adana basin: a near-coincidence of tectonic and eustatic forcing," Turkish Journal of Earth Sciences, vol. 22, no. 5, pp. 864-889, 2013.

[43] G. C. Schmidt, "Stratigraphic nomenclature for the Adana region petroleum district VII," Turkish Petroleum Administration Bulletin, vol. 6, pp. 47-63, 1961.

[44] Z. Ternek, "Adana havzasinın Alt Miosen (Burdigalien) formasyonları, bunların diğer formasyonlarla olan münasebeti ve petrol imkânları," Maden Tetkik ve Arama Enstitüsü Dergisi, vol. 49, pp. 48-66, 1957 (Turkish).

[45] C. Yetiş and C. Demirkol, "Adana Baseni Batı Kesiminin Detay Jeoloji Etüdü I,” Report 8037, Maden Tetkik ve Arama Enstitüsü, Adana, Turkey, 1986 (Turkish).

[46] C. Yetiş, "Geology of the Çamardı (Niğde) region and the characteristics of the Ecemiş fault zone between Maden Boğazı and Kamışlı," İstanbul Üniversitesi Fen Fakültesi Mecmuası, vol. 43, pp. 41-61, 1978 (Turkish).

[47] A. Poisson, Recherches Géologiques Dans Les Taurides Occidentales (Turquie) [Ph.D. thesis], Université Paris-Sud Orsay, Paris, France, 1977.

[48] E. Bingöl, "Explanatory notes to the metamorphic map of Turkey," in Explanatory Text for the Metamorphic Map of Europe, H. J. Zwart, Ed., pp. 348-354, UNESCO, Paris, France, 1978.

[49] N. Özgül, “Toroslar’ın bazı temel jeoloji özellikleri," Türkiye Jeoloji Kurumu Bülteni, vol. 19, no. 1, pp. 65-78, 1976 (Turkish).

[50] O. Tekeli, “Toroslarda, Aladağ ofiyolitli melanjının özellikleri," Türkiye Jeoloji Kurumu Bülteni, vol. 24, pp. 57-63, 1981 (Turkish).

[51] A. Polat and J. F. Casey, "A structural record of the emplacement of the Pozanti-Karsanti ophiolite onto the Menderes-Taurus block in the late Cretaceous, eastern Taurides, Turkey," Journal of Structural Geology, vol. 17, no. 12, pp. 1673-1688, 1995.

[52] A. Polat, J. F. Casey, and R. Kerrich, "Geochemical characteristics of accreted material beneath the Pozanti-Karsanti ophiolite, Turkey: Intra-oceanic detachment, assembly and obduction," Tectonophysics, vol. 263, no. 1-4, pp. 249-276, 1996.

[53] C. Yetiş, G. Kelling, S. L. Gökçen, and F. Baroz, "A revised stratigraphic framework for later Cenozoic sequences in the northeastern Mediterranean region," Geologische Rundschau, vol. 84, no. 4, pp. 794-812, 1995.

[54] M. N. Yalçın and N. Görür, "Sedimentological evolution of the Adana basin," in Proceedings of the International Symposium on the Geology of the Taurus Belt, O. Tekeli and M. C. Göncüoğlu, Eds., pp. 165-172, Maden Tetkik ve Arama Enstitüsü, Ankara, Turkey, 1984.

[55] R. Burton-Ferguson, A. E. Aksu, T. J. Calon, and J. Hall, "Seismic stratigraphy and structural evolution of the Adana
Basin, eastern Mediterranean," Marine Geology, vol. 221, no. 1-4, pp. 189-222, 2005.

[56] N. Görür, "Karaisalı kireçtaşının (Miyosen) sedimantolojisi," Türkiye Jeoloji Kurumu Bülteni, vol. 22, pp. 227-232, 1979 (Turkish).

[57] N. N. Özyurt, Aladağ (Kayseri-Adana) Karstik Akiferinde Yeraltısuyu Geçiş Zamanı Dağılımının İncelenmesi [Ph.D. thesis], Hacettepe University, Ankara, Turkey, 2005 (Turkish).

[58] L. Tezcan, M. Ekmekci, O. Atilla et al., "Assessment of climate change impacts on water resources of Seyhan River basin," 2007, http://www.chikyu.ac.jp/iccap/ICCAP_Final_Report/3/2hydrology_sg_tk.pdf.

[59] M. Biasioli, R. Barberis, and F. Ajmone-Marsan, "The influence of a large city on some soil properties and metals content," Science of the Total Environment, vol. 356, no. 1-3, pp. 154-164, 2006.

[60] V. E. Buhrke, R. Jenkins, and D. K. Smith, A Practical Guide for the Preparation of Specimens for X-Ray Fluorescence and X-Ray Diffraction Analysis, Wiley-VCH, New York, 1998.

[61] Y. Kataoka, "Standardless X-ray fluorescence spectrometry (Fundamental parameter method using sensitivity library," The Rigaku Journal, vol. 6, no. 1, pp. 33-39, 1989.

[62] F. R. Boyd and S. A. Mertzman, "Composition and structure of the Kaapvaal lithosphere, southern Africa," in Magmatic Processes: Physicochemical Principles, B. O. Mysen, Ed., pp. 1324, Geochemical Society Special Publication, Philadelphia, 1987.

[63] X. Wang and M. M. Maroto-Valer, "Dissolution of serpentine using recyclable ammonium salts for $\mathrm{CO}_{2}$ mineral carbonation," Fuel, vol. 90, no. 3, pp. 1229-1237, 2011.

[64] ArcMap 9.3.1., Environmental Systems Research Institute, Redlands, Calif, USA, 2009.

[65] APHA-AWWA-WEF, Standard Methods for the Examination of Water and Wastewater, American Public Health AssociationAmerican Water Works Association-Water Environment Federation, Washington D.C, 21st edition, 2005.

[66] C. Güler, "Site characterization and monitoring of natural attenuation indicator parameters in a fuel contaminated coastal aquifer: Karaduvar (Mersin, SE Turkey)," Environmental Earth Sciences, vol. 59, no. 3, pp. 631-643, 2009.

[67] R. A. Freeze and J. A. Cherry, Groundwater, Prentice-Hall, Upper Saddle River, NJ, USA, 1979.

[68] R Core Team, R: A Language and Environment for Statistical Computing, R Foundation for Statistical Computing, Vienna, Austria, 2014, http://www.R-project.org/.

[69] A. N. Kolmogorov, "Sulla determinazione empirica di una legge di distribuzione," Giornale dell'Istituto Italiano degli Attuari, vol. 4, pp. 83-91, 1933.

[70] N. Smirnov, "Table for estimating the goodness of fit of empirical distributions," Annals of Mathematical Statistics, vol. 19, pp. 279-281, 1948.

[71] J. C. Davis, Statistics and Data Analysis in Geology, John Wiley and Sons, New York, 3rd edition, 2002.

[72] C. Güler, M. Alpaslan, M. A. Kurt, and A. Temel, "Deciphering factors controlling trace element distribution in the soils of Karaduvar industrial-agricultural area (Mersin, SE Turkey)," Environmental Earth Sciences, vol. 60, no. 1, pp. 203-218, 2010.

[73] H. F. Kaiser, "The application of electronic computers to factor analysis," Educational and Psychological Measurement, vol. 20, pp. 141-151, 1960.

[74] Y.-Y. Chi, "Multivariate methods," Wiley Interdisciplinary Reviews: Computational Statistics, vol. 4, no. 1, pp. 35-47, 2012. 
[75] A. B. Costello and J. W. Osborne, "Best practices in exploratory factor analysis: four recommendations for getting the most from your analysis," Practical Assessment, Research \& Evaluation, vol. 10, no. 7, pp. 1-9, 2005.

[76] H. H. Harman, Modern Factor Analysis, 2nd edition, The University of Chicago Press, Chicago, Ill, USA, 1967.

[77] R. J. Rummel, Applied Factor Analysis, Northwestern University Press, Illinois, 1970.

[78] D. L. Parkhurst and C. A. J. Appelo, Description of Input and Examples for PHREEQC Version 3-A Computer Program for Speciation, Batch-Reaction, One-Dimensional Transport, and Inverse Geochemical Calculations, book 6, chapter A43, U.S. Geological Survey Techniques and Methods, 2013, http://pubs.usgs.gov/tm/06/a43/.

[79] J. E. Johnson, G. Anderson, and D. Parkhurst, thermo.com.V8 .R6.230, Version 1.11, Lawrence Livermore National Laboratory, 2000.

[80] C. Güler and G. D. Thyne, "Hydrologic and geologic factors controlling surface and groundwater chemistry in Indian WellsOwens Valley area, southeastern California, USA," Journal of Hydrology, vol. 285, no. 1-4, pp. 177-198, 2004.

[81] E. Bonifacio, E. Zanini, V. Boero, and M. Franchini-Angela, "Pedogenesis in a soil catena on serpentinite in north-western Italy," Geoderma, vol. 75, no. 1-2, pp. 33-51, 1997.

[82] J. I. Drever, The Geochemistry of Natural Waters: Surface and Groundwater Environments, Prentice-Hall, Inc., New Jersey, 3rd edition, 1997.

[83] Z. Y. Hseu, H. Tsai, H. C. Hsi, and Y. C. Chen, "Weathering sequences of clay minerals in soils along a serpentinitic toposequence," Clays and Clay Minerals, vol. 55, no. 4, pp. 389-401, 2007.

[84] O. Parlak, V. Höck, and M. Delaloye, "The supra-subduction zone Pozanti - Karsanti ophiolite, southern Turkey: Evidence for high-pressure crystal fractionation of ultramafic cumulates," Lithos, vol. 65, no. 1-2, pp. 205-224, 2002.

[85] D. L. Whitney and B. W. Evans, "Abbreviations for names of rock-forming minerals," American Mineralogist, vol. 95, no. 1, pp. 185-187, 2010.

[86] C. Oze, S. Fendorf, D. K. Bird, and R. G. Coleman, "Chromium geochemistry in serpentinized ultramafic rocks and serpentine soils from the Franciscan complex of California," American Journal of Science, vol. 304, no. 1, pp. 67-101, 2004.

[87] J. Kierczak, C. Neel, H. Bril, and J. Puziewicz, "Effect of mineralogy and pedoclimatic variations on $\mathrm{Ni}$ and $\mathrm{Cr}$ distribution in serpentine soils under temperate climate," Geoderma, vol. 142, no. 1-2, pp. 165-177, 2007.

[88] B. H. Robinson, R. R. Brooks, P. E. H. Gregg, and J. H. Kirkman, "The nickel phytoextraction potential of some ultramafic soils as determined by sequential extraction," Geoderma, vol. 87, no. 3-4, pp. 293-304, 1999.

[89] J. S. Caine, J. P. Evans, and C. B. Forster, "Fault zone architecture and permeability structure," Geology, vol. 24, no. 11, pp. 10251028, 1996.

[90] A. M. Piper, "A graphic procedure in the geochemical interpretation of water-analyses," Transactions American Geophysical Union, vol. 25, no. 6, pp. 914-928, 1944.

[91] T. Boschetti and L. Toscani, "Springs and streams of the Taro-Ceno Valleys (Northern Apennine, Italy): Reaction path modeling of waters interacting with serpentinized ultramafic rocks," Chemical Geology, vol. 257, no. 1-2, pp. 76-91, 2008.
[92] L. Daniele, Á. Vallejos, M. Corbella, L. Molina, and A. PulidoBosch, "Hydrogeochemistry and geochemical simulations to assess water-rock interactions in complex carbonate aquifers: The case of Aguadulce (SE Spain)," Applied Geochemistry, vol. 29, pp. 43-54, 2013.

[93] L. A. Robertson and J. G. Kuenen, "Aerobic denitrification: a controversy revived," Archives of Microbiology, vol. 139, no. 4, pp. 351-354, 1984.

[94] P. A. Domenico and F. W. Schwartz, Physical and Chemical Hydrogeology, John Wiley and Sons, Inc., New York, 1997.

[95] C. Güler, G. D. Thyne, J. E. McCray, and A. K. Turner, "Evaluation of graphical and multivariate statistical methods for classification of water chemistry data," Hydrogeology Journal, vol. 10, no. 4, pp. 455-474, 2002.

[96] S. Sarah, G. Jeelani, and S. Ahmed, "Assessing variability of water quality in a groundwater-fed perennial lake of Kashmir Himalayas using linear geostatistics," Journal of Earth System Science, vol. 120, no. 3, pp. 399-411, 2011.

[97] F. N. Ponnamperuma, "The chemistry of submerged soils," Advances in Agronomy, vol. 24, pp. 29-96, 1972.

[98] D. Bernard, J. El Khattabi, E. Lefevre, H. Serhal, S. BastinLacherez, and I. Shahrour, "Origin of nickel in water solution of the chalk aquifer in the north of France and influence of geochemical factors," Environmental Geology, vol. 53, no. 5, pp. 1129-1138, 2008.

[99] S. N. Davis, D. O. Whittemore, and J. Fabryka-Martin, "Uses of chloride/bromide ratios in studies of potable water," Ground Water, vol. 36, no. 2, pp. 338-350, 1998.

[100] EC, "Council Directive 98/83/EC of 3 November 1998 on the quality of water intended for human consumption," Official Journal of the European Communities, vol. L330, pp. 32-54, 2006.

[101] C. M. Bethke, The Geochemists Workbench, ver. 2.0: A user's guide to Rxn, Act2, Tact, React, and Gtplot, University of Illinois, Urbana, 1994.

[102] R. M. Garrels and F. T. Mackenzie, "Origin of the chemical compositions of some springs and lakes," in Equilibrium Concepts in Natural Water Systems, vol. 67 of Advances in Chemistry, pp. 222-242, American Chemical Society, Washington, D.C., 1967. 

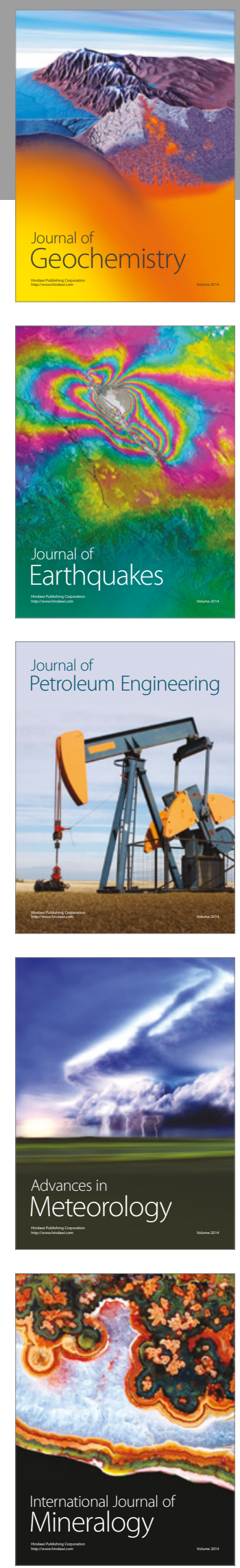
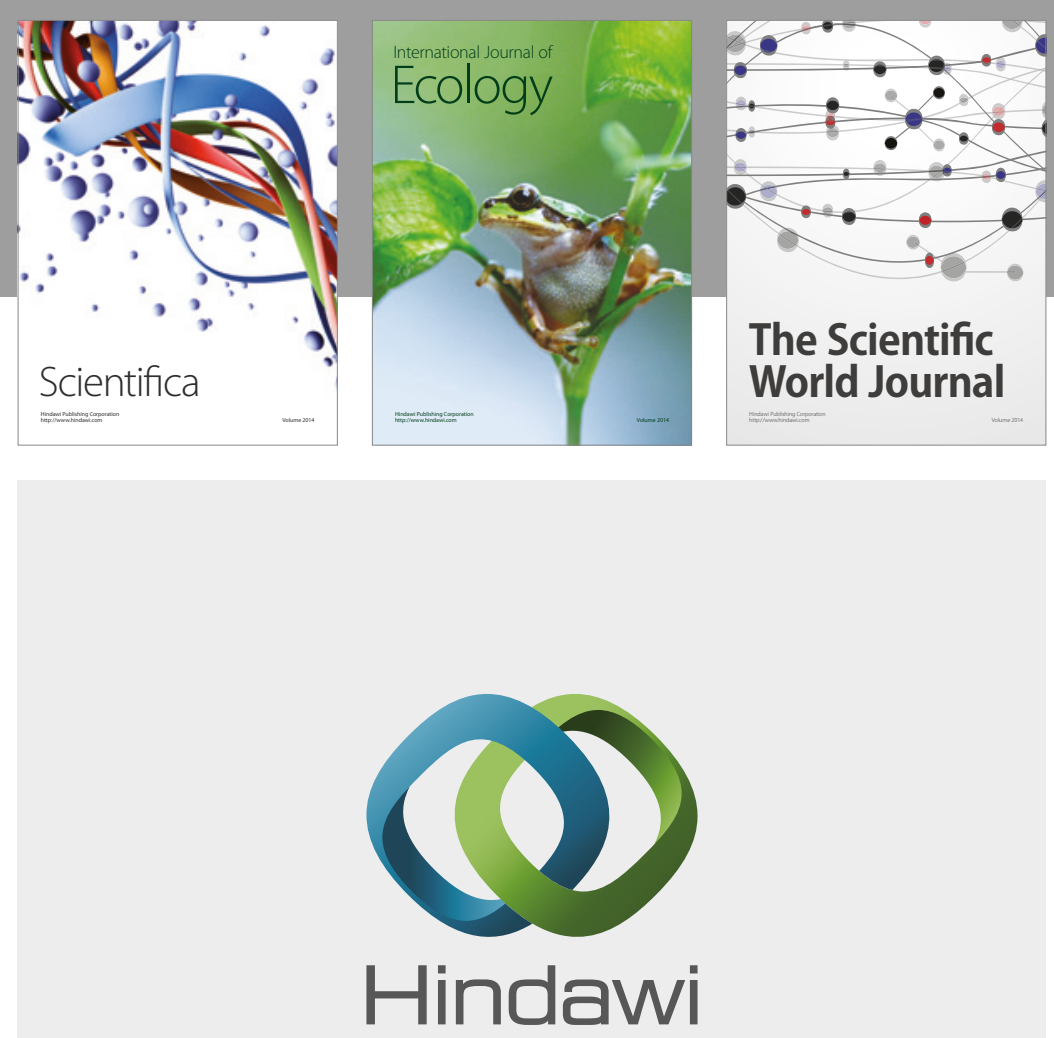

Submit your manuscripts at

https://www.hindawi.com
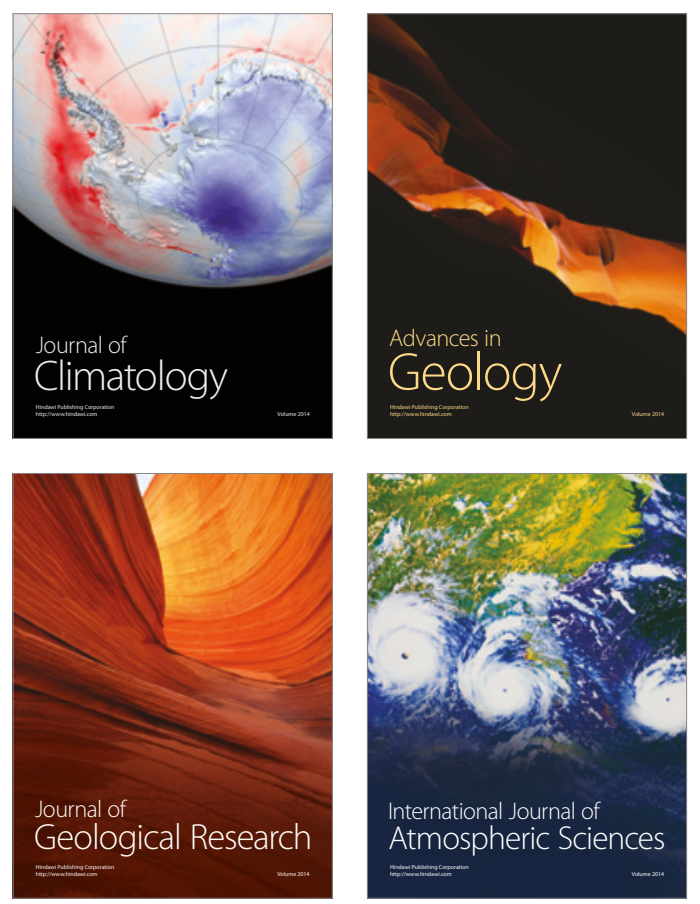

The Scientific

World Journal
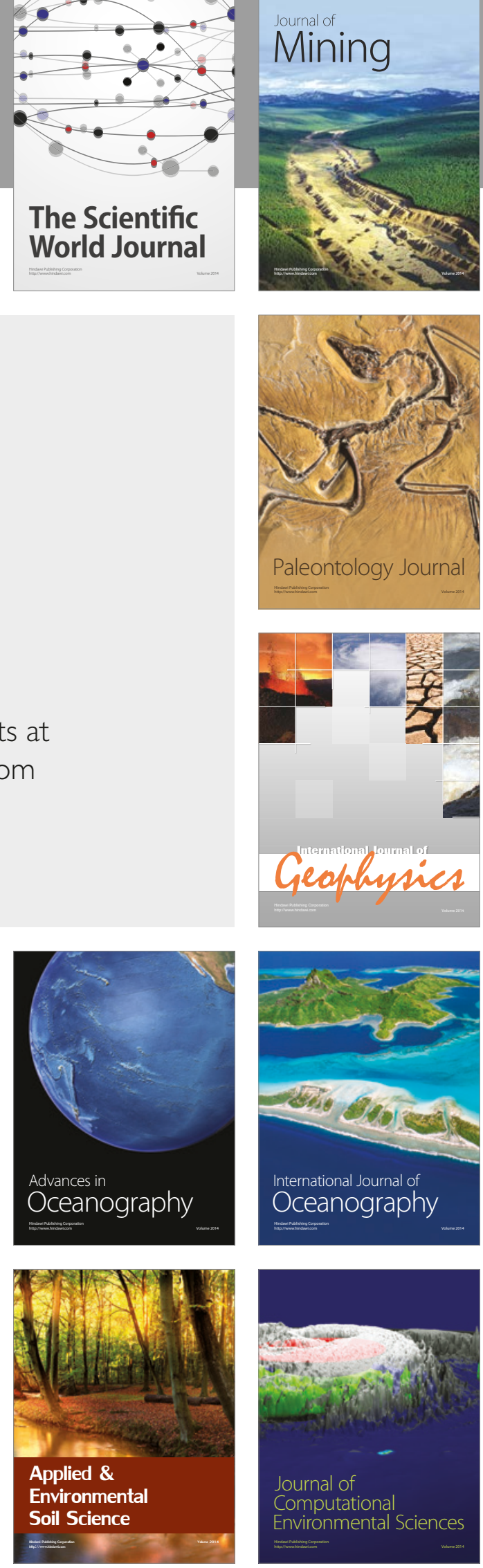